\section{Ankara Üniversitesi Eğitim Bilimleri Fakültesi Özel Eğitim Dergisi}

2021, 22(3), 699-723
ARAŞTIRMA

Gönderim Tarihi: 10.06.20

Kabul Tarihi: 27.01.21

Erken Görünüm: 02.02.21

\title{
Görme Engelli Bireylerin Matematik Eğitiminde İhtiyaçları ve Sorunları: Cebir Kavramları Bağlamında*
}

\author{
Fatma Nur Aktaşi 1
}

\author{
Ziya Argün ${ }^{2}$
}

$\ddot{O} \mathbf{z}$

Giriş: Görme yetersizliğine bağlı olmaksızın her öğrencinin cebir öğrenmede güçlükler yaşaması muhtemeldir. Ancak sembol, notasyon ve grafik gibi görsel unsurlara sahip olan cebir, görme engelli bireyler için önemli sınırlılıklar içermektedir. Bu nedenle bu araştırma, görme engelli bireylerin matematik öğrenme ve öğretme süreçlerindeki ihtiyaçlarını ve sorunlarını cebirsel kavramlar bağlamında tespit etmeyi amaçlamaktadır.

Yöntem: Bu çalışma, iç içe geçmiş çoklu durum çalışması deseninde tasarlanmıştır. 12 katılımcı amaçlı örnekleme metodlarından ölçüt örnekleme, maksimum çeşitlilik ve kartopu örnekleme metodları ile belirlenmiştir. Yarıyapılandırılmış görüşmeler ve video kaydı ile elde edilen veriler içerik analizi ile analiz edilmiştir.

Bulgular: Görme engelli bireylerin matematik eğitimi uygulamalarındaki ihtiyaçlarına ve sorunlarına ilişkin bulgular temalar altında toplanmıştır: Destek ve/veya bireyselleştirilmiş eğitim ihtiyacı, destek eğitim araçlarına ilişkin ihtiyaçlar, matematiğin doğasından kaynaklanan sorunlar, duyuşsal faktörler ve sınavlarda yaşanan sorunlar.

Tartışma: Elde edilen ihtiyaçların ve sorunların birbirini tetikleyen ilişkisel bir örüntü oluşturduğu tespit edilmiştir. Ayrıca, elde edilen temaların birbiriyle neden-sonuç ilişkisine dayalı tetikleyici faktörler olduğu söylenebilir.

Sonuç ve Öneriler: Sonuçlar matematik eğitimi özelinde ele alınmasına rağmen, büyük çerçevede destek eğitim uygulamalarını ve araçlarını kapsayan ihtiyaçlar elde edilmiştir. Belirlenen temaların her biri matematik eğitimde çözüm bekleyen bir problem olarak ele alınmalıdır. Ayrıca, görme engelli bireylerin değişken, bilinmeyen, denklem ve çözümü, eşitlik, eşitsizlik, fonksiyon kavramlarına dair yanılgılarının ve kavram bilgisinde eksikliklerin olduğu belirlenmiştir. Buna göre eğitim uygulamalarını geliştirecek kavram odaklı araştırmalara ihtiyaç vardır.

Anahtar sözcükler: Görme engelli bireyler, matematik eğitimi, cebir kavramları, ihtiyaçlar, sorunlar.

Atıf için: Aktaş, F. N., \& Argün, Z. (2021). Görme engelli bireylerin matematik eğitiminde ihtiyaçları ve sorunları: Cebir kavramları bağlamında. Ankara Üniversitesi Ĕ̌itim Bilimleri Fakültesi Özel Ĕ̈itim Dergisi, 22(3), 699-723. https://doi.org/10.21565/ozelegitimdergisi.750682

\footnotetext{
*Bu çalışma 2019 Uluslararası Türk Bilgisayar ve Matematik Eğitimi Sempozyumu 4'te sunulan "Görme Engelli Bireylerin Matematik Eğitiminde Mevcut Durum Analizi: İhtiyaçlar ve Sorunlar" adlı bildirinin genişletilmiş halidir.

1Sorumlu Yazar: Arş. Gör. Dr., Kahramanmaraş Sütçü İmam Üniversitesi, E-posta: fatmanuraktas@ksu.edu.tr, https://orcid.org/0000-0002-3804-3650

2Prof. Dr., Gazi Üniversitesi, E-posta: ziya@gazi.edu.tr, https://orcid.org/0000-0001-8101-7215
} 


\section{Giriş}

Eğitim, fiziki yapısı, güçlü ve zayıf özelliklerine göre ihtiyaçları doğrultusunda bireylere sunulması beklenen temel haklar arasında yer almaktadır. Bu ihtiyaçlar bağlamında İnsan Hakları Evrensel Beyannamesi ve Çocuk Hakları Sözleşmesi bireylerin gereksinimlerine uygun bireysel eğitim programlarını savunmaktadır. Ancak bu programlara tabi olan ve özel eğitime ihtiyaç duyan kaynaştırma öğrencileri için bireysel özelliklerine uygun ders programlarının, destek eğitim araçlarının ve değerlendirme süreçlerinin yetersiz olması dikkat çekmektedir (Zorluoğlu \& Sözbilir, 2017). Söz konusu öğrenciler arasında yer alan görme engelli bireyler, matematik eğitimi için sembol ve şekil gibi görsel unsurları gözlemleyemediğinden gereksinimleri olan öncelikli gruplar arasındadır. Nitekim görme engelli öğrencilerin öğrenme deneyimlerindeki görsel eksiklikler, akademik başarılarının düşük olmasına ve öğrenme çıktılarının yetersiz olmasına sebep olabilmektedir (Zebehazy vd., 2012). Bu nedenle görme engelli bireylerin matematik biliminden yoksun kaldığı ve kariyer seçimlerini bu yoksunluğuna dayalı gerçekleştirmeleri gerektiği söylenebilir. Dolayısı ile matematiğin doğasından ve soyut yapısından kaynaklanan güçlüklerin belirlenmesi ve çözüm önerilerinin sunulması bir gerekliliktir. Nitekim matematiksel içeriğin günlük yaşam becerilerine ve kalitesine katkısı dünya standartlarında (National Council of Teachers of Mathematics [NCTM], 2000) ve öğretim programlarında (Milli Eğitim Bakanlığ1 [MEB], 2018a, 2018b) vurgulanmaktadır. Özellikle cebir kavramlarının eğitim programlarındaki kaçınılmaz rolü, günlük yaşam becerilerinin gelişimi (Kieran,1992) ve öğretim programlarındaki yeri (MEB, 2018a, 2018b) bağlamında önem arz etmektedir. Ancak görme yetersizliğine bağlı olmaksızın her öğrencinin cebir öğrenmede güçlükler yaşadığını ortaya koyan çalışmalar (Cowan, 2011; Kieran, 1992) cebirsel kavramları öğretme ve öğrenme süreçlerinin incelenmesini gerekli kılmaktadır. Dolayısı ile cebir kavramları özelinde matematik eğitimi uygulamalarındaki ihtiyaçların ve sorunların belirlenmesi, öğrenmenin etkili olmasına ve zengin çıktılar elde edilmesine katkı sunacaktır

\section{Görme Engelli Bireyler ve Matematik Eğitimi}

Görme engellilik, terim olarak yasal, tıbbi ve eğitsel tanımlarının yanı sıra körlük (total) ve az gören gibi sınıflandırmalara sahiptir (Aydın \& Akça-Bayar, 2017). Buna göre eğitsel uygulamalarda bütün düzeltmelere rağmen iki gözle görmesi $1 / 10$ 'den daha az yararlanabilen bireyler total görme engelli olarak adlandırılmaktadır. Ayrıca, iki gözle görmesi 1/10 ile 1/30 arasında olan ve görme yetisinden yararlanmak için özel destek araçlarına ihtiyaç duyan bireyler az gören olarak tanımlanmaktadır. Dünya Sağlık Örgütü (2009) ise sınıflandırmada görme alanı, renk ve 1şık algısı gibi faktörlerin de dikkate alınması gerektiğini vurgulamıştır. Zira sınıflandırmalar görme yetersizlik derecesi ve görme duyusunu kullanma geçmişi, bireyin bilişsel düşünme becerisinde ve kavram öğrenme stratejisinde rol aldığı için önemlidir (Edwards vd., 1995). Bu nedenle gerçekleştirilen araştırmada görme engelli birey terimi; görme oranı, görme alanı ve nitelikleri dikkate alınarak az gören ve kör bireyleri kapsamaktadir.

Karshmer ve diğerleri (2007) görme engelli bireyler için matematik eğitimine dair iki görüşün varlığından bahsetmektedir. Bu görüşlerden biri, görme engelli bireylerin soyut ve görsel matematiksel içerikten muaf olması iken, diğeri bilişsel düzeyde söz konusu kavramları öğrenmede güçlüklerin olmadığını savunmaktadır. İkinci görüşe göre bireylerin sadece diğer duyularına hitap eden destek eğitim araçlarına ihtiyaçları olduğu belirtilmektedir. Nitekim Türkiye'de daha önce görme engelli öğrenciler matematik öğretim programında soyut ve görsel içeriklerden muaf tutulurken, Özel Eğitim Yönetmeliği'nde (2018) yapılan değişiklik ile bireysel farklılıklara uygun destek eğitim araçları kullanılarak bu içeriklere yer verilmesi hükmü yer almıştır. Görme engelli bireyler için kullanılan destek eğitim araçları ise daktilo, küptaş, iğneli sayfa ve çeşitli bilgisayar destekli programlarla sınırlıdır. Ancak Türkiye'de görme oranına bağlı olarak görme engelliler ilkokullarının ve ortaokullarının yanı sıra bu düzeylerde kaynaştırma okulları seçeneği yer alırken, ortaöğretim düzeyinde bireyler kaynaştırma eğitimine yönlendirilmektedir. Kaynaştırma eğitimi uygulamalarında yer alan matematik öğretmenlerinin özel eğitimde kaynaştırma uygulamalarına ilişkin yetersizliklerinin olması ve kabartma yazıda matematiğe hakim olmamaları dikkat çekmektedir (Hacısalihoğlu-Karadeniz, 2017; Karshmer vd., 2007). Dolayısıyla destek eğitim araçlarının yetersizliğinin yanı sıra öğretmen yetersizliklerinin olması kaynaştırma uygulamalarına dair ihtiyaçların belirlenmesinin gerekliliğini işaret etmektedir. Literatür incelendiğinde, görme engelli öğrenciler için çeşitli somut materyallere (Bülbül vd., 2012; Horzum \& Bülbül, 2017) ve bu öğrencilerin kavrayışlarına ilişkin (Aktaş, 2020; Cowan, 2011; Maulana, 2019; Spindler, 2006) çalışmalar yer almaktadır. Ancak görme yetersizlik düzeyine göre bireylerin matematiksel dil kullanımı (Aktaş \& Argün, 2020) ve kavram öğrenme (Maulana, 2019) süreçlerindeki farklılıkları dikkat çekmektedir. Dolayısıyla öncelikle görme engelli bireylerin görme yetersizlik düzeylerine göre matematikte soyut ve görsel kavramların öğretim uygulamalarına dair mevcut durumlarının ve ihtiyaçların belirlenmesi gerekmektedir. Böylece görme engelli bireyler için tasarlanacak olan öğretim uygulamaları ve destek eğitim araçları için önemli ipuçları elde edilebilecektir. 


\section{Görme Engelli Bireyler İçin Cebirsel Kavramların İncelenmesi}

Cebir kavramları üzerine düşünme süreçleri, aritmetikten ilișkisel düşünme becerisine bir köprü görevi görmektedir (Kieran, 1992). Bu görev detaylı incelendiğinde sayılar arasındaki ilişkiyi keşfetme, sembol ile ifade etme, genellemelere ulaşma ve bilinmeyen niceliklerle işlemler yapma becerileri karşımıza çıkmaktadır. NCTM (2000) cebirin, geometri ve veri işleme kavramları gibi matematiğin alt öğrenme alanları ile olan ilişkisine dikkat çekmektedir. Bu nedenle temel cebir kavramlarının matematik öğrenme ve günlük hayat problemlerini çözme süreçlerine, başka bir ifade ile ilişkilendirme becerisine katkısı vurgulanmaktadır. Ayrıca ilişkilendirme becerisi fonksiyon kavramı çerçevesinde değişken, eşitlik ve denklem gibi temel cebirsel kavramlarıyla ilişkilidir (Argün vd., 2014).

Temel cebir kavramlarına ilişkin görme engelli bireylerin kavrayışları ve anlamaları üzerine yapılan araştırmalar incelendiğinde, görme duyusuna dayalı ihtiyaçlar bağlamında öğrenmede benzerlikler ve farklılıklar ortaya konulmuştur (Aktaş, 2020; Knauff \& May, 2006; Maulana, 2019; Spindler, 2006). Knauff ve May (2006) görme duyusunun ilişkilendirme becerisine yansımasını belirlemek üzere görme yetersizlik düzeyi ve geçmişi (görme yetersizlik düzeyi ve görme kaybının ne zaman oluştuğu) farklılık gösteren bireyler ile gerçekleştirdiği çalışmada, görme yetisinden yararlanma düzeyinin ve süresinin düşünme becerisini artırdığını belirlemiştir. Buna göre doğuştan görme engelli olan ve/veya total görme engelli bireylerin soyut matematiksel kavramları algılamakta daha fazla güçlük yaşadığı tespit edilmiştir. Ayrıca çalışmada, görme yetersizliği olmayan ve gözleri bağlanmış bireylerin de sıralı ikilileri işaretleyememe ve doğru parçalarını takip edememe gibi benzer güçlükleri yaşadığ1 ortaya konulmuştur. Ancak doğuştan görme engelli bireylerin sembolleştirme ve görsel içerikler için yaşanılan güçlükler karşısında, hakim oldukları stratejiler (iki elleriyle takip etme, kutucukları sayma vb.) ile rahatlıkla çözüm ürettikleri gözlenmiştir. Benzer şekilde Cowan (2011) görme engelli ortaöğretim ve üniversite öğrencileri ile gerçekleştirdiği çalışmasında, katılımcıların doğrusal fonksiyonları somut düşünmede ve fonksiyonun temsil türleri arasında dönüşümleri anlamlandırmada başarılı olduğunu tespit etmiştir. Ancak görme engelli öğrencilerin kullandıkları destek eğitim araçlarından dolayı eşitlik kavramına ve dolayısı ile denklem çözme sürecine dair kavram yanılgılarının olduğu da bilinmektedir (Aktaş, 2020; Cansu, 2014). Bununla birlikte Maulana (2019) görme engelli bireylerin değişkenler ile işlemler yapmasının ve bu işlemleri takip etmesinin güçlüğüne dikkat çekmiştir. Bu sonuçlar görme engelli öğrencilerin cebirsel temsil ve bununla ilişkili kavramlara dair ihtiyaçlarının ortaya konulmasının gerekliliğine işaret etmektedir. Bir diğer temsil türü olan grafik ise görme engelli öğrenciler için görsel unsurlar içerdiğinden bir sınırlılık olarak düşünülebilir (Şafak, 2005). Ancak Cowan (2011) bireylerin parmak ucu hassasiyetini dikkate alan destek eğitim araçları ile bu sınırlılı̆̆ın ortadan kaldırılabileceğine dikkat çekmektedir. Bülbül (2013) çalışmasında, çeşitli grafik tasarımı araçlarının görme engelli bireyler için ayrı ayrı yetersizlikler barındırdığını belirlemiştir. Bu gerekçelere dayanarak şimdiki araştırmada temel cebir kavramları olarak değişken, bilinmeyen, eşitlik, denklem, genelleme, fonksiyon kavramlarına ve bu kavramların temsil türlerine odaklanılmıştır.

İhtiyaç belirleme, mevcut durumu ortaya koyarken beklentileri ve bu beklentileri gerçekleştirirken yapılması gerekenleri belirlemeye imkân sunmaktadır. Nitekim eğitim uygulamalarında ihtiyaç belirleme, müfredat geliştirme çalışmalarından bir dersi planlamaya kadar her adımda karşımıza çıkmaktadır (Kılıç vd., 2019). Daha özel olarak görme engelli bireyler için tasarlanacak eğitim programlarında ve uygulamalarda, öğrencinin engel düzeyi ve yapabildiği ya da güçlük yaşadığı hususların tespiti tercih edilecek stratejilerin belirlenmesine katkı sunacaktır (Spindler, 2006). Bu bağlamda bu araştırmanın amacı, Türkiye' de görme engelli bireylerin matematik eğitimi uygulamalarındaki ihtiyaçlarını ve sorunlarını belirlemektir. Bu genel amaç altında görme engelli bireylerin sınıf uygulamalarından değerlendirme stratejilerine kadar geniş çerçevede matematik eğitimindeki mevcut durumlarını incelemek mümkün olacaktır. Ayrıca cebirsel kavramlar özelinde görme engelli bireylerin matematik içeriğine ilişkin mevcut durumunu ve kavram öğretimine ilişkin ihtiyaçlarını ortaya koymak amaçlanmaktadır. Bu amaçlar doğrultusunda araştırmanın problemleri şöyle sıralanabilir:

1. Görme engelli bireylerin matematik eğitimi uygulamalarındaki ihtiyaçları ve sorunları nelerdir?

2. Görme engelli bireylerin cebir kavramlarına dair öğrenme ihtiyaçları nelerdir?

\section{Yöntem}

\section{Araştırma Deseni}

İhtiyaçlar, Kılıç ve diğerleri (2019) tarafından mevcut durum ile olması istenilen durum arasındaki farklılıklar olarak açıklanmaktadır. Gerekliliklerin ortaya çıkarılması olarak yorumlanan ihtiyaçların ve sorunların belirlenmesi, bir durumun detaylı betimlenmesine dayanmaktadır (Kılıç vd., 2019). Bu nedenle bu çalışma, mevcut 
durumu kendi bağlamında inceleyerek sonuçları bütüncül bir yorumla ortaya koymaya firsat sunan durum çalışması deseninde (Merriam, 1998) tasarlanmıştır. Ayrıca ihtiyaç belirleme çalışması, merkezine aldığı bireyin potansiyeline ulaşmasında mevcut durumu incelemeye odaklanmaktadır (Kılıç vd., 2019). Bu çalışmada görme engelli bireylerin matematik eğitiminde ihtiyaçlarını ve sorunlarını belirlemek amaçlandığından, her bir katılımcı araştırmanın bir durumunu oluşturmaktadır. Dolayısı ile her bir durum (katılımcı) kendi içinde farklılıklar barındırdığından, çalışma iç içe geçmiş çoklu durum deseninde tasarlanmıştır (Yin, 2003).

\section{Çalışma Grubu}

Araştırmanın katılımcıları amaçlı örnekleme metoduna göre tespit edilmiştir. Görme yetersizlik düzeyine ve görme kaybının meydana geldiği zaman dilimine göre görme engelli bireylerin sözlü ve yazılı matematiksel dil kullanım becerileri farklılık göstermektedir (Aktaş \& Argün, 2020). Bu nedenle genel perspektifte ihtiyaçları ve sorunları belirlemek için farklı demografik özelliklere sahip, görme yetersizlik türleri ve geçmişi farklılık gösteren katılımcılar maksimum çeşitlilik örnekleme metodu ile belirlenmiştir. Böylece söz konusu farklılıklara dayanarak ortak bir örüntü yakalamak ve çeşitliliği gözlemlemek mümkün olmuştur (Patton, 2014). Ayrıca her bir katılımcı, görüşmelerin ardından zengin bilgiler sunacağını düşündüğü görme engelli bireyler ile irtibat kurulmasına katkı sunmuştur. Benzer öneriler tekrar etmeye başladığında (18 katılımcıdan sonra), veri toplama süreci sona erdirilerek kartopu örnekleme metoduna yer verilmiştir. Katılımcıların görme oranları Rehberlik Araştırma Merkezi (RAM) ya da doktor raporu ile belirlenmesinin yanı sıra büyük punto Latin harf ya da braille yazı kullanma, renk-1şık algılarının olması/olmaması ve eşlik eden başka bir engellin olmaması kriterlerine göre ölçüt örnekleme metodu kullanılmıştır. Katılımcıların RAM ve doktor raporları arasındaki tutarsılıklar ve bireyin renk-1şık algısına ilişkin ifadeleri dikkate alınarak, katılımcılara çeşitli puntolarda Latin alfabe yazılar gösterilmiş ve kabartma yazı bilme/kullanma düzeyi sorulmuştur. Verilen kod isimlere göre Ankara, İstanbul, Eskişehir ve Aksaray illerinden katılımcılara ait bilgiler Tablo 1'de yer almaktadır.

Tablo 1

Katılımcllara Ait Bilgiler

\begin{tabular}{|c|c|c|c|c|c|c|c|}
\hline $\begin{array}{l}\text { Ad1 } \\
(\text { Kod) }\end{array}$ & $\begin{array}{c}\text { Görme kayb1 } \\
\text { (RAM/doktor } \\
\text { raporu) }\end{array}$ & $\begin{array}{c}\text { Görme kaybının } \\
\text { yaşandığı } \\
\text { zaman dilimi }\end{array}$ & $\begin{array}{c}\text { Iş1k } \\
\text { alg1s1 }\end{array}$ & $\begin{array}{l}\text { Renk } \\
\text { alg1s1 }\end{array}$ & $\begin{array}{c}\text { Braille } \\
\text { bilme/ } \\
\text { kullanma } \\
\end{array}$ & $\begin{array}{l}\text { Latin alfabe bilme/ } \\
\text { kullanma }\end{array}$ & Okul/meslek \\
\hline K1 & $\% 85$ & Doğuştan & Var & Yok & Evet & Hayır & Anadolu Lisesi (12.sınıf) \\
\hline $\mathrm{K} 2$ & $\% 80$ & Doğuştan & Var & Var & Evet & Evet (kullaniyor) & Anadolu Lisesi (12.sınıf) \\
\hline $\mathrm{K} 3$ & $\% 90$ & Doğuştan & Var & Yok & Evet & Hayır & $\begin{array}{l}\text { Anadolu İmam Hatip Lisesi } \\
\text { (Mezun) }\end{array}$ \\
\hline $\mathrm{K} 4$ & $\% 85$ & Doğuştan & Var & Var & Evet & Hayır & Anadolu Lisesi (Mezun) \\
\hline K5 & $\% 90$ & Doğuştan & Var & Var & Evet & Hayır & İmam Hatip Lisesi (Mezun) \\
\hline K6 & $\% 90$ & 12 Yaşında & Var & Var & Evet & Evet (kullanmiyor) & Sosyal Hizmetler Bölümü (2.sınıf) \\
\hline K7 & $\% 85$ & Doğuştan & Var & Var & Evet & Evet (kullanmiyor) & Türkçe Öğretmenliği (1.sınıf) \\
\hline K8 & $\% 90$ & Doğuştan & Var & Var & Evet & Hayır & Sosyoloji Bölümü (2.sınıf) \\
\hline K9 & $\% 90$ & 7-12 yaş arası & Var & Var & Hayır & $\begin{array}{l}\text { Evet (18 punto- } \\
\text { mercek kullaniyor) }\end{array}$ & Makine Mühendisliği (3.sınıf) \\
\hline K10 & $\% 90$ & 7-10 yaş arası & Yok & Yok & Evet & $\begin{array}{l}\text { Evet (sadece } \\
\text { yazabiliyor) }\end{array}$ & Psikoloji Bölümü (4.sınıf) \\
\hline K11 & $\% 70$ & $12-20$ yaş arası & Var & Var & Hayır & $\begin{array}{l}\text { Evet (16 punto- } \\
\text { mercek kullaniyor) }\end{array}$ & Bilgisayar Mühendisi \\
\hline K12 & $\% 85$ & $1-25$ yaş arası & Var & Var & Evet & $\begin{array}{l}\text { Evet (sadece } \\
\text { yazabiliyor) }\end{array}$ & Akademisyen \\
\hline
\end{tabular}

\section{Veri Toplama Araçları}

$\mathrm{Bu}$ araştırmada yarı-yapılandırılmış bireysel görüşmeler yoluyla veriler elde edilmiştir. Görüşmelerde görme engelli bireylerin demografik bilgilerini, matematiksel bilgi düzeyini, matematik öğretim ortamlarına ve uygulamalarına ilişskin ihtiyaçlarını ve sorunlarını belirlemek amaçlanmıştır. Bu bağlamda tasarlanan görüşme formunda yer alan sorular; görme engellilik düzeyine, matematik öğrenme süreçlerine, günlük yaşam becerilerinde 
matematiksel kavramlarına, cebir kavramlarına ilişkin bilgilerine ve eksikliklerine odaklanmaktadır. Öncelikle görme engelli bireylerin ihtiyaçlarını ve sorunlarını ele alan çalışmalar incelenmiştir (Bayram, 2014; Bitter, 2013; Bülbül vd., 2012; Edwards vd., 1995; Karshmer vd., 2007; Kızılaslan \& Sözbilir, 2018; Spindler, 2006). Cebirsel kavramlar için kavramların doğası, tanımları, öğrenci kavrayışları ve öğretim programları incelenmiştir (Argün vd., 2014; Kieran, 1992; MEB, 2018a, 2018b). Bu inceleme görme engelli bireyler için matematik öğretimine ilişskin çalışmalarla harmanlanmıştır (Aktaş, 2020; Bülbül, 2013; Cansu, 2014; Cowan, 2011; Şafak, 2005). Tasarlanan görüşme formu matematik, matematik eğitimi ve görme engelliler eğitimi alanında üç akademisyenden uzman görüşü alınarak düzenlenmiştir. Uzman görüşleri doğrultusunda görme engellilik düzeyi için çeşitli puntolarda yazılan metinleri görebilme ve cisimleri renklerine göre ayırt edebilme adımları eklenmiştir. Düzeltmelerin ardından gerçekleştirilen pilot çalışma ile görüş̧e formu son halini almıştır. Pilot çalışmaya doğuştan total görme engelli (renk ve ışık algısı yok) ve \%80 oranında görme kaybına sahip iki 12. sınıf öğrencisi katılmıştır. Az gören katılımcı kaynaştırma okullarında eğitim hayatını sürdürmüşken, total görme engelli katılımcı ise ilkokul ve ortaokul eğitimini görme engelliler okullarında tamamlamıştır. Total görme engelli katılımcı braille yazı, küptaş kasa ve yazı tableti araçlarını ve az gören birey 14 punto ile yazılmış metinler kullanmaktadır. Pilot çalışmaların ardından görüşme formunda kabartma yazı ve grafiklere ilişkin düzenlemeler yapılmıştır. Bu düzenlemelerde nokta vuruş sıklığı ve çeşitliliği gibi dokunsal materyallerde değişiklikler yapılmıştır.

Görüşme formu 'kişisel bilgiler', 'matematik eğitimine ve uygulamalara ilişkin bilgiler' ve 'cebir kavramlarına ilişkin bilgiler' başlıklarından oluşmaktadır. Kişisel bilgiler altında bireyin görme engellilik düzeyine, eğitim durumuna ve kullandıkları destek eğitim araçlarına ilişkin sorular yer almaktadır. Matematik eğitimine ve uygulamalara ilişkin bilgiler bölümünde, bireylerin matematik öğretimi uygulamalarındaki tecrübelerini, sorunlarını ve ihtiyaçlarını belirlemeyi, söz konusu uygulamaların etkililiğine dair bilgi edinmeyi, matematiksel kavramlara ilişkin görüş̧lerini almayı amaçlayan sorulara yer verilmiştir. Cebir kavramlarına ilişkin bilgiler bölümünde ise cebirsel kavramlar (değişken, eşitlik, fonksiyon vb. ve temsil türleri) için görme engelli bireylerin güçlükleri, kullandıkları somut materyalleri ve bu cebirsel kavramlara dair tanım, algı ve hata gibi anlamalarına dair eksiklikleri belirlemek amacıyla sorular tasarlanmıştır. Görüşme formundan örnek sorular aşağıda sunulmuştur:

1. Kişisel bilgiler: Kaynaştırma eğitimi uygulamalarında karşılaştığınız güçlükler neler(di)? Öğretim uygulamalarında yararlandığınız materyaller neler(di)? Bu materyallerden kaynaklanan sorunlarınız olduysa paylaşabilir misiniz?

2. Matematik eğitimine ve uygulamalara ilişkin bilgiler: Hatırladığınız etkili bir matematik dersinizi paylaşabilir misiniz? Matematik ögrenirken sizi zorlayan noktalar neler(di)? Matematik dersinde destek eğitim araçlarına ihtiyaç duyduğunuz kavramlar varsa açıklayabilir misiniz?

3. Cebir kavramlarına ilişkin bilgiler: Değişken, denklem ve fonksiyon gibi cebir kavramlarını öğrenirken yaşadığınız güçlükler neler(di)? Öğretmenlerinizin bu kavramlar için kullandığı stratejilerde karşılaşıı̆ınız güçlükler neler(di)? Bir hayvanat bahçesinde günlük tüketilen yem miktarını gösteren tabloyu inceleyiniz. Bu iki küme arasındaki ilişkiyi nasıl temsil edersiniz? Aşağıdaki grafiklerden hangisi bu ilişkiyi temsil etmektedir? Bu ilişkiyi cebirsel olarak ifade edebilir misiniz? Hayvanat bahçesinde tüketilen yem miktarı örneği için fonksiyon kavramını inceleyebilir misiniz?

Görüşmelerde katılımcıların düşünme süreçlerini etki altında kalmadan belirleyebilmek için aşina oldukları kabartma yazı ya da büyük puntoda metin, diyagramlar ve grafikler kullanılmıştır (bk. Şekil 1). Kabartma yazı metinler için matematiksel ifadeler ve grafikler TactileView programında düzenlenmiştir.

\section{Şekil 1}

Görüşmelerde Tablo ve Grafik Temsilinde Kullanılan Dokunsal Materyal Örnekleri
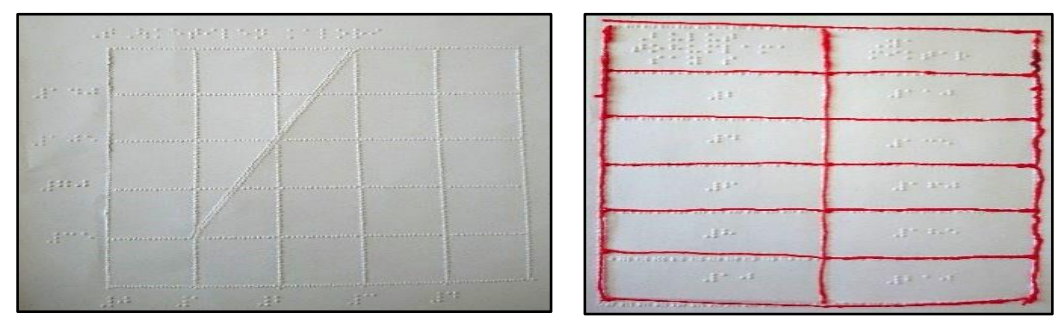
Diyagram ve grafikleri incelerken görme engelli bireylerin el hareketleri önem arz ettiğinden görüşmeler video kaydına alınmıştır. Bu kayıtlar, araştırmanın diğer veri toplama araçlarını oluşturmaktadır. Katılımcılardan görüşmelerin yapılması ve video kaydına alınması için onam formu alınmıştır.

\section{Verilerin Toplanması ve Analizi}

Yarı-yapılandırılmış görüşmeler, katılımcılarla sessizliği sağlanmış mekânlarda yürütülmüştür (sınıf veya araştırmacının odası). 90-120 dakika arasında farklılık gösteren bir veya iki oturumda gerçekleştirilen görüşmeler, katılımcının el hareketlerine de odaklanacak şekilde video kaydına alınmıştır. Katılımcıların kendilerini daha rahat ifade etmesi ve onları daha yakından tanımak için katılımcılar ve bazı katılımcıların (lise öğrencilerinin) aileleri ile birlikte yaklaşık 15 dakikalık tanışma ve katılım onayı görüşmeleri yapılmıştır. Tablo 2'de araştırma süreci betimlenmiştir.

Tablo 2

Araştırma Süreci Takvimi

\begin{tabular}{ll}
\hline \multicolumn{1}{c}{ Araştırma süreci basamakları } & \multicolumn{1}{c}{ Tarih } \\
\hline Görüşme formunun tasarlanması & Şubat 2018 \\
Görüşme formu uzman görüşü \& pilot uygulama & Mayıs 2018 \\
Görüşme formunun uyarlanması & Nisan 2018 \\
Görüşmeler için katılımcıların belirlenmesi ve görüşmelerin gerçekleştirilmesi & 25 Nisan-10 Ağustos 2018 \\
Verilerinin transkript ve analiz edilmesi & 20 Ağustos-20 Aralık 2018 \\
\hline
\end{tabular}

Verilerin analizinde Merriam (1998) içerik analizi adımları takip edilmiştir. Bireysel görüşmelerden elde edilen veriler söylemler ve el hareketleri dikkate alınarak, araştırmanın amacı doğrultusunda transkript edilmiş ve bir kez sadece okunmuştur. Ardından her bir katılımcı için önemli ifadeler işaretlenmiş, yansıtıcı notlar alınmış ve kategoriler oluşturulmuştur. Yapılan literatür incelemesi (Bitter, 2013; Edwards vd., 1995; Kızılaslan \& Sözbilir, 2018; Spindler, 2006) 1şı̆̆ında kategoriler ele alınmıştır. Aynı içeriği vurgulayan cümleler ve/veya ekran görüntüleri birkaç katılımcıda ya da tek bir katılımcıda birkaç kez tespit edildi ise ayrı bir kategori olarak belirlenmiştir. Tek bir ana fikir altında toplanabilen kategoriler temalar altında ele alınmıştır. Verilerin analizine ilişkin örnek Tablo 3'te sunulmuştur.

Tablo 3

\begin{tabular}{|c|c|c|c|}
\hline Tema & Kategori & Açıklama & Katılımcı örneği \\
\hline $\begin{array}{l}\text { Destek } \\
\text { eğitim } \\
\text { araçlarına } \\
\text { ilişkin } \\
\text { ihtiyaçlar }\end{array}$ & $\begin{array}{r}\text { Not tutma } \\
\text { güçlüğü }\end{array}$ & $\begin{array}{l}\text { Araç kullanarak ya da okuyucu birey } \\
\text { yardımıyla ders içeriğini, metinleri, } \\
\text { sembolleri, işlemleri not tutarken kullanılan } \\
\text { materyalden kaynaklanan sorunlar; kolay ve } \\
\text { zengin not tutma ihtiyacı }\end{array}$ & $\begin{array}{l}\text { K5: "Tablet kalemde tak çıkar her işlemde } \\
\text { zor oluyor. Küptaşı da lisede işlemlerde hiç } \\
\text { kullanamadım. İşlem yapmak zor olunca, } \\
\text { matematik de zor geliyor." }\end{array}$ \\
\hline $\begin{array}{l}\text { Matematiğin } \\
\text { doğasından } \\
\text { kaynaklanan } \\
\text { sorunlar }\end{array}$ & $\begin{array}{l}\text { Matematiksel } \\
\text { işlemlerin } \\
\text { sıklığ1 }\end{array}$ & $\begin{array}{l}\text { Problem çözme, denklem ve çözümü, } \\
\text { sembolik temsiller gibi rakam, sembol ve } \\
\text { işaret içeren matematiksel işlemlerin birbiri } \\
\text { ardına devam etmesi ve bu işlemleri bireyin } \\
\text { zihinden takibinin güç olması }\end{array}$ & $\begin{array}{l}\text { K12: “İşlem uzunluğu çok olduğunda işlemi } \\
\text { kafadan yapabiliyorum, ama belli bir süre } \\
\text { sonra unutuyorum. Üst üste bir sürü işlem } \\
\text { olduğunda birbirine karış1yor. Bölü işaretini } \\
\text { tek nokta görüp çarptığım oldu.” }\end{array}$ \\
\hline $\begin{array}{l}\text { Duyuşsal } \\
\text { faktörler }\end{array}$ & $\begin{array}{l}\text { Bireylerin } \\
\text { tutumu }\end{array}$ & $\begin{array}{l}\text { Görme engelli bireylerin matematik öğrenme } \\
\text { süreçlerine dair öğretmenlerin, akranların ve } \\
\text { okuyucu bireylerin tutumu; sınavlarda ve } \\
\text { sınıf uygulamalarında okuyucu birey desteği } \\
\text { için bireylerin tutumu }\end{array}$ & $\begin{array}{l}\text { K10: "Görme engelliler matematikçi olamaz } \\
\text { diye bir algı var. Bence olabilir, ancak } \\
\text { entegre etmek yerine dişlıyoruz. Lisedeki } \\
\text { hocalarım da aynı şekilde böyle } \\
\text { davransaydı, 'sen nerde kullanacaksın, biz } \\
\text { sana +, - soralım geçirelim' deseydi ben şu } \\
\text { an burada olmayacaktım." }\end{array}$ \\
\hline
\end{tabular}

Verilerin analizinde elde edilen kategorilerin kapsamı ve bu kategorilerin uygun temalar altında toplanması bağlamında araştırmacılar fikir birliğine varmıştır ve görme engelliler bölümünde uzman bir araştırmacıdan görüş alınmıştır. Bu süreçte araştırmacılar semboller ve işaretler kategorisini iki farklı bağlamda düşünerek ayrı temaların altında ele alınmasına kanaat getirmiştir. Çünkü matematiksel sembollerin ve işaretlerin sıklığından, Latin ve braille alfabelerde farklı yazı dilinden kaynaklanan güçlükler barındırdığı için semboller ve 
işaretler kategorisi 'matematiğin doğasından kaynaklanan sorunlar' teması altında ele alınmıştır. Ayrıca sınavlarda okuyucu bireylerle matematiksel dile dayalı iletişim güçlüğünün yaşanması semboller ve işaretler kategorisinin 'sınavlarda yaşanan sorunlar' teması altında da ele alınmasını gerektirmiştir.

\section{Araştırmacının Rolü}

Yazarlar araştırmacı rolü ile çalışmayı tasarlamış, sürdürmüş ve kaleme almıştır. Görüşmeler ilk yazar tarafından gerçekleştirilmiştir. Görüşmelerde araştırmacı, kabartma yazı kullanan katılımcılara hazırlanan dokümanları incelemeleri için ‘Önündeki metni inceleyebilir misin?' ve 'Başka bir grafik veriyorum.' şeklinde yönlendirici açıklamalarda bulunmuştur. Ayrıca araştırmacı iki ay boyunca haftada bir gün bir görme engelliler ortaokulunda gözlemler yapmıştır ve bir özel eğitim kurumunda görme engelli 12. sınıf öğrencilerine gönüllü olarak bireysel matematik dersleri sunmuştur. Böylece görme engelli bireyler ile matematiksel iletișim süreci hakkında deneyim kazanmıştır. Yapılan gözlemler ise görme engelli bireylerin ihtiyaç ve sorunlarına ilişkin görüş̧e sorularının yapılandırılmasına katkı sunmuştur.

\section{Geçerlik ve Güvenirlik Çalışmaları}

Araştırmanın inanırlı̆ı̆ını (Patton, 2014) artırmak için uzun süreli etkileşime ve uzman incelemesine yer verilmiştir. Bunun için katılımcılar ile görüşmelerden önce yaklaşık yarım saat sohbet etme ve araştırma hakkında bilgi verme firsatı oluşturulmuştur. Katılımcılar kartopu örnekleme metodu ile belirlendiği için oluşan güven ortamı uzun süreli etkileşim stratejisine katkı sunmuştur. Araştırma sonuçlarının aktarılabilirliği amaçlı örnekleme metodu ile sağlanmıştır. Ölçüt ve maksimum çeşitlilik örnekleme metodları ve katılımcıların betimlenmesi bu amaca hizmet etmiştir. Veri toplama araçları için uzman görüşlerinin alınması ve pilot çalışmanın yapılması da araştırmanın güvenirliğini artırmıştır. Veri analizleri için ikinci kodlayıcı ile fikir birliğine varılması tutarlılığa katkı sunmuştur.

\section{Bulgular}

$\mathrm{Bu}$ bölümde katılımcıların matematik eğitimi uygulamalarında ortaya çıkan ihtiyaçları ve sorunları öncelikle ele alınacaktır. Böylece cebir kavramları özelinde matematiksel kavramlara ve bu kavramların öğretimine ilişkin ihtiyaçların ve sorunların yorumlanması mümkün olacaktır.

\section{Matematik Eğitimi Uygulamalarındaki İhtiyaçlar ve Sorunlar}

Katılımcıların matematik eğitimi ve öğretiminde sınıf uygulamaları, ulusal sınavlar ve ders geçme sınavları, destekleyici öğretim uygulamaları ve bireylerle iletişim gibi karşılaş̧ıkları sorunlar ve bu sorunların yol açtığı ihtiyaçlar Tablo 4'te sunulmuştur.

\section{Tablo 4}

Görme Engelli Bireylerin Matematik Eğitimi Uygulamalarındaki İhtiyaçları ve Sorunları

\begin{tabular}{|c|c|}
\hline Temalar & Kategoriler \\
\hline \multirow{10}{*}{ Destek ve/veya bireyselleştirilmiş eğitim ihtiyacı } & Öğretim stratejisi \\
\hline & Sözlü anlatım ve betimleme ihtiyacı ve sorunları \\
\hline & Sınıf düzenine dair ihtiyaçlar \\
\hline & Tekrar etme ihtiyaci \\
\hline & Tecrübe eksikliğine dayalı sorunlar \\
\hline & Dersi takip edememe sorunu \\
\hline & Dokunsal iletişim eksikliği \\
\hline & $\begin{array}{c}\text { Okuyucu birey ihtiyacı ve sorunları } \\
\text { • Akran desteği ihtiyacı }\end{array}$ \\
\hline & • Okuyucu-öğrenci etkileşimi \\
\hline & - Okuyucu bireye dair sorunlar \\
\hline \multirow{6}{*}{ Destek eğitim araçlarına ilişkin ihtiyaçlar } & Yazılı materyal ihtiyacı \\
\hline & Teknolojik materyal ihtiyacı \\
\hline & Somut materyal ihtiyacı \\
\hline & Not tutma güçlüğü \\
\hline & Ekran okuyucu sorunu \\
\hline & Ses kaydi sorunu \\
\hline
\end{tabular}


Tablo 4 (devami)

\begin{tabular}{ll}
\hline \multicolumn{1}{c}{ Temalar } & \multicolumn{1}{c}{ Kategoriler } \\
\hline Matematiğin doğasından kaynaklanan sorunlar & Kisaltma kullanma sorunu \\
& Latin harfleri ve rakamları bilmeme \\
& Zihinden işlem yapma güçlüğü \\
Braille yazı ile matematiğin güçlüğü & Matematiksel işlemlerin sıklığ1 \\
Duyuşsal faktörler & Semboller ve işaretler \\
Matematiksel formüller \\
Binavlarda yaşanan sorunlar & Kaygi tutumu (öğretmen, akran ve okuyucu birey) \\
& Motivasyon kaybı \\
& Okuyucu birey sorunu \\
& Semboller ve işaretler \\
\hline
\end{tabular}

Katılımcıların matematik eğitimindeki ihtiyaçları ve sorunları incelendiğinde, destek/bireyselleştirilmiş eğitim ihtiyaçları, destek eğitim araçları, duyuşsal faktörler, sınavlarda yaşanan sorunlar ve matematiğin doğasından kaynaklanan ihtiyaçlar ve sorunlar başlıkları altında ele alınabilmektedir. Kategoriler incelendiğinde ise ihtiyaçların ve sorunların genel olarak eğitim-öğretim uygulamalarında karşılaşılan not tutma güçlüğü, kaygı, okuyucu birey sorunu ve akran desteği gibi problemleri içerdiği gözlenmektedir (bk. Tablo 3). Ancak bu ihtiyaçlar ve sorunlar matematik uygulamalarında matematiğe dair içeriklere odaklı ortaya çıkmaktadır. Ayrıca katılımcılar için matematiğin soyut ve sembolik yapısı matematiğin doğasından kaynaklanan sorunları da beraberinde getirmiştir.

\section{Destek ve/veya Bireyselleştirilmiş Eğitim İhtiyacı}

Özel eğitime ihtiyaç duyan görme engelli bireylerin matematik eğitimi özelinde destek eğitim uygulamalarına ve bireyselleştirilmiş eğitim fırsatlarına ihtiyaç duyması kaçınılmazdır. Bu ihtiyacı meydana getiren en dikkat çeken kategori katılımcıların ve onların öğretmenlerinin birlikte matematik öğrenimi-öğretimi gerçekleştirmedeki tecrübe yetersizliğidir. İlköğretim eğitimlerini görme engelliler okulunda tamamlayan katılımcılar, ortaöğretimde kaynaştırma uygulamasına tabi olmalarıyla dersi takip etme ve sınıf düzeni gibi çeşitli güçlüklerle karşılaştıklarını belirtmişlerdir. Bu güçlüklerin üstesinden gelmeleri ve matematik öğretmeniyle kabartma yazının dışında Latin alfabesinde iletişim kurmalarının sorun olması, katılımcıların matematiksel iletişimde ve çevreye adapte olmada tecrübesiz olmalarından kaynaklandığı belirlenmiştir. Benzer şekilde daha önce görme engelli bireye öğretim uygulamaları tasarlamayan ve bu konuda eğitim geçmişi olmayan matematik öğretmeninin de tecrübe eksikliği olduğu katılımcılar tecrübelerine dayanarak vurgulamıştır. Nitekim katılımcıların tümü kaynaştırma okullarında destek eğitim uygulamalarından yararlanmadıklarını belirtmiştir. Eğitim hayatını kaynaştırma okullarında devam ettiren K9 bu durumu "Ben liseyi bitirdiğimde dört işlem ile sınava hazırlanmaya başladım. Çünkü bir şey bilmeden beni geçiriyorlardı. Okumayı bile ilkokul dörtte öğrendim. Çünkü benimle ilgilenmediler hiç. (...) Az görenlerin sayısal bölümde okuması büyük bir sıkıntı. Yani örneği yok, ilk kez benim gibi bir öğrenci mühendislik bölümüne gelmiş. İlk olmak çok kötü bir şey. Görmeyen bireyi anlayabiliyorlar, ama az gören bireyi anlayamıyorlar." ifadeleri ile açıklamıştır. K9'un ifadelerinde öğretmenlerin az gören öğrenciler ile matematiksel iletişim kurmada yaşadığı güçlüklerin yanı sıra, öğrencinin söz konusu tecrübe yetersizliğinden kaynaklanan sorun dikkat çekmektedir. Benzer şekilde K6 da üniversite düzeyinde matematik derslerinde yaşadığ 1 sorunlardan bahsetmiştir.

K6: (...) üniversitede de matematik dersim var, iki senede anca verebildim. O hocamız da 'ben sana nasıl anlatacağım bunları' diye düşünüyordu. Şu anda istatistik dersim var, maalesef aynı sorunlarla karşılaşıyorum.

Öğretmenlerin özel eğitim uygulamalarına dair bilgi ve tecrübe eksikliğini vurgulayan başka bir bulgu ise öğrencilere uygulamada tecrübeler kazandırmayla ilgilidir. K12 matematik ile günlük hayatı ilişkilendirirken, görme engelli öğrencinin somut yaşantılarla tecrübe etmedeki yetersizliklerden söz etmiştir. K12'ye göre “(...) görme engelli doğuştan sınırlandırılmamışsa, bir havuza gidip dokunmamışsa (...) ya da hayatında hiç mumla 
oynamamış, mumun nasıl yandığını zamanla nasıl eridiğini bilmiyorsa belki de eksiklik olabilir” ifadeleri ile hayatın içinde matematiksel bilgiden yoksun kalınabildiğini belirtmiştir. Katılımcılar her ne kadar kaynaştırma sınıflarında matematik derslerine katılsa da dersi takip etmede güçlük yaşadıklarını belirtmiştir.

K1: Matematikte açıkçası sınıfın matematiğine katılamıyorum, çünkü hoca da anlatamıyor, zaten sınıfla birlikte beni idare edemiyor ve arkadaşlarım da bana okurken kendileri defterlerine yazamadıkları için matematik konusunu ayrıca özel ders alarak sağlamaya çalışıorum.

$\mathrm{K} 1$ 'in ifadesinde öğretmenin tecrübesindeki yetersizlik ve ders takibinde yaşanan güçlüklerin yanı sıra dikkat çeken diğer bulgu okuyucu birey ihtiyacıdır. Burada K1'in akran desteği ile sınıfta ders takibini sağlamaya çabaladığı açıktır. Tecrübe eksikliği ve okuyucu birey ile iletişim sorunu birbiri ile ilişkili kategoriler olarak karşımıza çıkmaktadır. Katılımcılara göre matematiksel içerik hakkında iletişim kurma, görsel içeriği açıklama ve sembolik dil kullanma okuyucu birey için tecrübe ve bilgi gerektirdiği söylenebilir. Benzer şekilde katılımcıların, özellikle ilk defa kaynaştırma eğitimine tabi olanların, öğretmenleri, akranları ve okuyucu bireyler ile matematiksel iletişim kurması önemli bir sorun olarak belirlenmiştir. Okuyucu birey yetersizliği sorununu güçlendiren değişkenlerden diğeri sözlü anlatımdaki yetersizlikler olarak kategorilendirilmiştir. Başka bir ifade ile katılımcıların kendileri için tasarlanacak olan matematik dersinde betimsel bir dil kullanımına ihtiyaç duydukları açıktır. Ancak katılımcılara göre öğretmenlerin veya okuyucu bireylerin diyagram gibi görsel içerikleri ve matematiksel sembolleri betimlemede yetersiz olduğu ya da isteksiz olduğu söylenebilir. K7, matematiksel işlemlerin takibi ve sembollerin algılanması için betimleyici bir dil kullanılmasının önemini şöyle ifade etmiştir:

K7: (...) matematik öğretmenim mesela bir soru anlatıyor şöyle çözüyor; 'İște şunu şuradan aldık, şunu şunla çarptık, sonra şunla topladık, sonuç şu'. Ne kadar 'Sayıları okur musunuz?' desem de ya yarıya kadar okuyordu ya da hiç tam olarak okumuyordu.

K10 ise izlediği videolarda yer alan matematiksel denklemler için akran desteğine ihtiyaç duyduğunu vurgulamıştır. Okuyucu birey ihtiyacı ders içeriklerinin tekrar edilmesinde de ortaya çıkmaktadır. Nitekim ders takibinde güçlük yaşaması bireyin not tutmada da güçlüklerle karşılaşmasına neden olduğundan, anlatılanların tekrar edilmesinde gören akranlardan ya da öğreticilerden okuyucu desteğine ihtiyaç duyulmaktadır. Ayrıca sınıf düzeni ders takibini güçleştiren değişkenlerdendir. Çünkü kaynaştırma sınıflarında görme engelli bireylerin tahtadaki bilgiye okuyucu birey desteği ile erişmesi, bireyin ve akranlarının sınıftaki oturma düzenini etkilemektedir. K4 sınıftaki görme engelli olmayan akranları için ifadelerinde oturma düzeninden şöyle bahsetmiştir:

K4: (...) arkadaşımın dikkati dağılıyordu, onun için pek soramıyordum, arkada oturmayı tercih ediyorlard1.

Bir diğer katılımcı K12 ise akran desteği ve oturma düzenine ilişkin sorunlarını şu şekilde ifade etmiştir:

K12: Ben tahtadaki bilgilere çok ulaşabildiğimi söyleyemem (güler). Yani kalkıp tahtaya yakından bakıp bir satır, iki satır ya da kaç cümle artık okuyabiliyorsam, tekrar yerime oturup bu şekilde çok git gellerim olduğunu hatırlıyorum. Ama belli bir süre sonra artık 'önümden çekil göremiyorum' gibi tepkiler oluştuğu için bıraktım. Bu sebepten çok az bir durumda yanımdaki arkadaşımın seslendirmesini istemiş olabilirim.

Sözlü anlatım, betimleyici dil gibi bahsi geçen ihtiyaçlar ve sorunlar katılımcılar için öğretim stratejilerin önemine dikkat çekmektedir. Ögretim stratejilerindeki sorunlar sözlü anlatımdaki betimleyici dilin olmaması, dikkat çekici etkinliklere ve somut materyallere yer verilmemesi gibi sorunları içermektedir. K7 matematiksel işlemlerin ve sembolik gösterimlerin yer aldığı dersler arasında yaptığı karşılaştırma ile öğretim stratejisine dair soruna yer vermiştir:

K7: Kimya öğretmenim çok iyiydi, çok güzel anlatırdı. Her şeyi bana sorardı, hani hiç 'şu görsel' demezdi, bütün işlemleri özellikle anlatırdı, tekrar tekrar anlamadığımda. Kimya da sayısal bir ders ama anlıyordum. Ama matematik öğretmenim öyle anlatmadı. Onun için başarılı olamadım.

Öğretim stratejileri ve betimleyici dili destekleyen bir diğer kategori ise dokunsal iletişime yer verilmemesidir. Görme engelli bireylerin tasarlanan somut materyallere, denklem çözümünde birbiri ardına takip eden işlemlere ve diyagram gibi görsel unsurlara dokunması öğrenmenin gerçekleşmesi için önem arz etmektedir. Ancak katılımcıların söz konusu uygulamaların eksikliğinin yanı sıra avuç içine çizme, ellerinin şekil üzerinde gezdirilmesi veya dokunsal araçlarla çalışma gibi dokunsal iletişime dair aktivitelerin eksikliğinden söz etmiştir. Örneğin; K3 sayı doğrusu kavramını sezgisel bir doğru çizerek öğrendiği şöyle ifade etmiştir: 
K3: Liseden mezun olduktan sonra özel eğitim kurumunda bir öğretmenim eliyle elimi tutarak masanın üzerine şöyle (işaret parmağı ile masa üzerine soldan sağa doğru bir çizgi çizerek) bir doğru çizdirmişti. Bu sayı doğrusu demişti.

\section{Destek Ĕ̆itim Araçlarına İlişkin İhtiyaçlar}

Katılımcıların matematik öğretimi uygulamalarında ve kavram öğrenme sürecinde çeşitli materyallere ihtiyaç duyduğu belirlenmiştir. Braille alfabe veya büyük punto metinlerin basımına ve erişimine dair ihtiyaçlar yer almaktadır. Ancak bu ihtiyacın, denklem ve sembol gibi görsel matematiksel içeriklerin yaygın kullanılan ekran okuyucu programlar tarafından okunamaması sorunu tarafından öne çıkarıldığı söylenebilir. Ayrıca braille yazıda veya büyük puntoda yazı yazmanın getirdiği güçlükler göz önüne alındığında katılımcılar için not tutma önemli bir sorun olarak belirlenmiştir. Nitekim kabartma yazı tabletiyle not tutmak güç olduğundan ve braille alfabede matematiksel semboller için kullanılan yazı karakterlerin sayısı fazla olduğundan katılımcıların gereksinimleri dikkat çekmektedir. K1 daktilo ve tablet gibi materyallerin not tutma için yetersiz kaldığını ifade etmiştir:

$\mathrm{K} 1:$ (...) basit bir daktilo icat edilse taşınabilme açısından sıkıntım olmasa, böyle istediğimiz her yere götürsek ve mesela katlanabilir bir şey olsa.

Katılımcıların bu sorunu bertaraf etmek için en sık başvurdukları yollardan biri ses kaydı almaktır. Fakat ses kaydı yapılmış kaynakların ve ders sunumların yetersizliği önemli ihtiyaçlar olarak karşımıza çıkmıştır. Ayrıca ses kaydına dair dikkat çeken sorunlar, alınan ses kayıtları dinlenirken ortaya çıktığı belirlenmiştir. Katılımcılardan K6, bu genel sorunu özetlemektedir.

K6: Ses kaydı alıyordum, ama dinlerken 40 dakikalık bir ders süresinde dinlemek istediğim 5 dakikalık kısmı bulmak uzun zaman alıyordu. (...) Matematik hocamız sınıfın kontrolünü sağlayamazdı, çok gürültü olurdu. Zaten pek bir şey duyamazdım, ses kaydında da çıkmazdı tabi o gürültüden.

Ses kayıtlarını dinlerken katılımcıların karşılaştığı güçlükler, diğer destek eğitim materyallerine ilişkin ihtiyaçlar ve sorunlar göz önüne alındığında teknolojik materyallerin geliştirilmesi kategorisini desteklemektedir. Örneğin, katılımcılardan K1 not tutma güçlüğünü artıran değişkenler arasında taşınması ve kullanımı ergonomik olmayan teknolojik materyallerden söz etmiştir. K11 büyüteçler ile okumanın güçlüğünden ve bilgisayar destekli programların yetersizliğinden bahsetmiştir. K3 ise teknolojik programların eksikliğinden bahsetmiştir:

K3: Yazılı materyallerimiz yok, ekran okuyucu programlar için kaynakları elektronik dokümana dönüştürmek gerek, ama biz cep telefonu ile taratamıyoruz. Bizim için çok güç bir şey.

K9 ise büyük punto ile yazılmış kaynakları anlamakta ve hafızada tutmakta güçlük yaşadığını belirtmiş ve bu nedenle sesli videoların ya da dilediği kısmı dinleyebileceği seslendirme programlarının önemli ihtiyaçlar olduğunu vurgulamıştır.

K3, K7 ve K12 ise matematik derslerinde kullanılabilecek somut materyallerin eksikliğinden söz etmiştir. K3 küptaş kasa materyalinin taşlarındaki karakterlerin yetersizliğinden ve ergonomik olmayışından bahsederken, $\mathrm{K} 12$ ise trigonometri öğretiminde kullanılan birim çember materyali gibi somut materyallerin kullanılmasının gerektiğini belirtmiştir.

\section{Matematiğin Doğasından Kaynaklanan Sorunlar}

Destek eğitim uygulamalarına ve araçlarına olan ihtiyaçlar incelendiğinde, bu gereksinimlere matematiğin soyut, sembolik ve görsel doğasından kaynaklanan sorunların zemin hazırladığı belirlenmiştir. Matematiğin sembolik yapısı özellikle doğuştan görme engelli katılımcılar için önemli bir engel teşkil ettiği söylenebilir. Katılımcılar cebirsel kavramlarda, sembollerin ve işaretlerin sıklıkla kullanılmasında, okuyucu bireyler tarafından betimlenmesinde ve kabartma yazıda temsil edilmesinde güçlükler yaşadıklarını belirtmişlerdir. Latin ve braille alfabedeki sembollerin temsil farklılıklarının, katılımcıların okuyucu ve öğretici bireylerle matematiksel dil kullanımında ve dolayısıyla matematiksel iletişimde güçlükler yaşamalarına neden olduğu tespit edilmiştir. Tamamen görme yetisini kaybeden katılımcıların matematik öğrenmede karşılaştıkları sorunların temelinde Latin harfleri ve rakamları bilmemeleri, matematiksel sembollerin ve işaretlerin sıklıkla kullanılması yer almaktadır. Latin alfabede matematiksel sembollerin ve işaretlerin kullanılması, braille yazı kullanan katılımcılar için yeni bir matematiksel dil teşkil ettiğini söyleyebiliriz. Katılımcıların her iki alfabede de matematiksel sembollerin ve işaretlerin kullanıma dair bilgi sahibi olması beklendiği belirlenmiştir. Ancak kaynaştırma uygulamalarında görme engelli bireyler ile öğretim tecrübesi olmayan ve braille kodlara hakim 
olmayan matematik öğretmenlerinin ve okuyucu bireylerin matematiksel iletişimi ve dolayısıyla kavramsal anlamayı güçleştirdiği söylenebilir. Ayrıca braille kod ile matematiksel sembollerin ve işaretlerin temsilinin birden fazla kod içermesi (örneğin, rakam işaretinin kullanılması gibi), bireylerin bu kodlara hakim olmaması ve matematiksel işlemleri not almadaki zorluklar braille yazıda matematik yapmanın güçlüğü kategorisini oluşturmuştur. Braille alfabesinde kullanılan çeşitli kısaltmaların yanı sıra, katılımcıların bilmedikleri kodlar yerine matematiksel semboller ve işaretler için kendilerine özgü kısaltmalar kullandığı belirlenmiştir. İlerleyen yaşlarda görme yetersizliği yaşayan K6 bireysel kullandığı sembol alternatiflerinden söz etmiştir:

K6: Kabartma yazıyı da sonradan öğrendiğim için matematik işaretlerinin çoğunu bilmiyordum ve ben de mesela kök işareti yerine kök yazıyordum (...) bana ait mesela log:tab gibi kisaltmalar yaparak o şekilde yazardım.

Katılımcılar kullandıkları kısaltmalardan dolayı okuyucu bireyler ile ortak bir matematiksel dil kullanmadıklarını ve zamanla bireysel kısaltmalarını unuttuklarını belirtmiştir. Ayrıca katılımcılar matematiksel sembollerin birbiri ardına sıralanan matematiksel işlemler ile daha karmaşık bir hal aldığını ifade etmiştir. Nitekim katılımcıların sembolik dil kullanımı ve braille yazı ile not tutma zorluklarından dolayı matematiksel işlemleri takip etmede güçlük yaşadıkları belirlenmiştir. Örneğin K1 yaşadığı sorunları şöyle açıklamışı̧ır:

K1: (...) Görme oranı biraz daha yüksek olup da işlemleri alt alta yazabilseydim, belki daha etkin bir şekilde matematik yapabilirdim. Ama braille-de birazcık matematik yapmak da bence zor oluyor (...) alt alta yazamadığım için taraf tarafa götürme yöntemleri falan var denklem konusunda, onları anlayamıyorum mesela.

K8 ve K12 ise denklem çözümlerinde işlem basamaklarını takip edemediğini vurgulamıştır. Böylece matematiksel işlemlerin slklığı, braille yazının doğası ve not tutma gibi çeşitli nedenlerden dolayı katılımcılar için matematik başarılarının önünde bir engel olduğunu söyleyebiliriz. Ayrıca katılımcılar not tutmada yaşadıkları güçlükten dolayı zihinden işlem yapmayı tercih ettiklerini, ancak işlemleri art arda takip edemediklerini vurgulamıştır. Dolayısıyla özellikle cebirsel ifadeler ile denklem çözümünde katılımcıların zihinden işlem yapma güçlüğü yaşadıkları belirlenmiştir.

Katılımcılar matematiğin doğası gereği sembolik dilin kullanılması ve işlemlerin takibi gibi engellerin yanı sıra matematiksel formüllerin sıklğından bahsetmiştir. K3 formül olarak adlandırdığı cebirsel ifadeleri ve matematiksel genellemeleri zihninde tutmakta güçlük yaşadığını belirtmiştir.

K3: Mesela şöyle bir olay var $(x+y)^{2}=x^{2}+2 x y+y^{2}$, bu direk bildiğiniz bir formüldür. Bunu $x^{2}+y^{2}+$ $2 x y$ diye söylediler bir ara, o zaman kafam allak bullak oldu. (...) Kümeleri görmüştük 9.sınıfta anlamaya çalışmıştım parantezler falan vardı mesela işaretlerden dolayı anlayamamıştım, aklımda kalmadı mesela (...).

Matematiğin doğasında yer alan sembol ve işaret kullanımın yanı sıra diyagram, grafik ve şekiller de katılımcıların matematiği öğrenmelerinde ve başarılı olmalarında sınırlılık teşkil ettiği belirlenmiş̧ir. Ancak buradaki sınırlılı̆̆ın, katılımcılar için söz konusu içeriklerin erişilebilir hale dönüştürülmemesinden kaynaklandığı tespit edilmiştir. Bu nedenle matematik öğreniminde görsel içeriğe erişim sorunu matematik eğitimindeki sorunlar arasinda yer almaktadır.

\section{Duyuşsal Faktörler}

Katılımcıların matematik öğretimi ve öğrenimi sürecinde bireyler ile iletişimleri sadece bilişsel içeriklere dair etkileşimlerle sınırlı kalmayıp, ayrıca duyuşsal olarak yansımaları belirlenmiştir. K3 bu durumu şöyle açıklamıştır:

K3: [...] Öğretmenin şefkatle yaklaşması yeterli değil, anlatmak için istekli olmalı. Matematiğin benim için gerekli olmadığını düşünerek öylesine anlatıyorsa şefkatli olmasının da bir önemi yok (...).

Ayrıca ilköğretim eğitiminin tamamını ya da bir kısmını görme engelliler okullarında tamamlayan katılımcıların, kaynaştırma uygulamasıyla ilk karşılaştı̆ğ öğrenim yaşantısında güçlükler yaşadıkları belirlenmiştir. K6 ögretmenlerin ve akranlarının tutumunu şu şekilde anlatmıştır:

K6: Lise döneminde çok net hatıllıyorum, 'ben farklıyım' düşüncesiyle zaten okula gidiyorsunuz. Pekiştireçler olduğu zaman o düşünce sizde sabit kalıyor. Matematik dersinde hocamız görsel bir konuyu anlatıyordu, tahtaya bir şeyler çizdi, yani sözel olarak da bir şey anlatmıştı. O yüzden sordum 'hocam 
anlatabilir misiniz ne soruyor soruda?' dedim. 'Bu seni ilgilendirecek bir şey değil' dedi. Bütün sınıfın içinde çok ciddi bir şeydi, o günden sonra hocaya bir şey sormadım zaten.

K6'nın ifadelerinden kaynaştırma uygulamalarına adapte olma sürecinde yaşadığı kaygı ve öğretmenin tutumu matematik başarısının devamı için önem arz ettiği açıktır. Nitekim K10 matematik öğrenme sürecine ilişkin tutumunun kariyer gelişimine yansıdığını ifade etmiştir.

K10: Baya ilgim var, matematik en sevdiğim dersti diyebilirim. Çok seviyorum, hatta bir ara matematik öğretmeni olmayı düşünüyordum. Ama sonradan vazgeçtim. Çünkü önümüze engel koyuluyor, birçok meslek için bu var zaten. Akademisyenler bile bunu böyle düşündüğü için toplum da zaten belli.

Öğretmenlerin sınıftaki tutumunu vurgulayan K7' nin ifadeleri şöyledir:

K7: Ben yokmuşum gibi davranıyordu matematik öğretmenim. Mesela 'şu soruyu da sen çöz' diyebilirdi ya da bir şekilde iletişim kurarsın, sonuçta öğretmensin, ama bu hiçbir şekilde olmuyordu, bir iletişimimiz yoktu sinifta.

Katılımcılar öğretmenlerinin yanı sıra akranlarının benzer tutumlara sahip olduğunu ve hatta ders takibinde okuyucu olarak destek olmak istemediklerini belirtmiştir.

\section{Sinavlarda Yaşanan Sorunlar}

Matematik ders geçme sınavları ve ulusal sınavlar bağlamında değerlendiren katılımcılar, slnav türü ve görsel içerik gibi değerlendirme sürecine dair sorunların yanı sıra okuyucu bireylere ilişkin sorunlardan söz etmiştir. Katılımcılar ders geçme sınavlarında açık uçlu sorular ve ulusal sınavlarda çoktan seçmeli sorulara göre daha başarılı olduklarını belirtmişlerdir. Bu nedenle sınav türünün önemli olduğunu söyleyebiliriz. Ancak katılımcıların ulusal sınavlarda daha başarısız olmalarının nedenleri ayrıntıll incelendiğinde, metinlerin okunmasına yardımc1 olan okuyиси bireyin tutumuna ve matematik sembol bilgisine dayalı motivasyon ve matematiksel iletişim sorunları dikkat çekmektedir. Katılımcılar sınavlarda yardımcı olan bireylerin genellikle matematiksel kavramlara ve sembollere ilişkin bilgilerinin yetersiz olduğunu, ayrıca soruları tekrar tekrar okumak için isteksiz olduklarını belirtmiş̧ir. Bu sorunlar katılımcıların motivasyonlarının azalmasına ve matematiksel iletişimdeki eksikliğe dayalı hatalara neden olmaktadır.

\section{Cebir Kavramlarına Dair Öğrenme İhtiyaçları}

Matematik öğretimi ve öğrenme süreçlerine dair ihtiyaçlar ve sorunlar için elde edilen boyutlar göz önüne alındığında, katılımcıların cebir kavramlarına ilişkin bilgi eksikliklerinin olması kaçınılmazdır. Nitekim katılımcılar arasında her ne kadar matematik akademik başarısı ve motivasyonu yüksek bireyler yer alsa da katılımcıların temel cebir kavramlarına dair kavram bilgilerinin eksik olduğu belirlenmiştir. Öncelikle katılımcıların ilköğretim düzeyinden başlayarak süregelen öğrenim hayatı boyunca karșllaștı̆̆ denklem ve çözümü basamaklarında eksiklikleri dikkat çekmektedir. Katılımcıların özellikle problemde verilen bilgileri ve bilinmeyeni tespit etmede, bu tespite göre denklemi ifade etmede ve cebirsel işlemleri gerçekleştirmede güçlükler yaşadıkları belirlenmiştir. Burada katılımcıların kavram bilgisindeki temel ihtiyacın bilinmeyeni tespit etme ve cebirsel ifadelerle işlem becerisi üzerine olduğu söylenebilir. Örneğin, K2'nin denklem yazmak yerine dört işlemi çeşitli kombinasyonlarda tekrarlayarak doğru cevaba ulaşmaya çabaladığı, K5' in ise problem çözümü için kurduğu denklemin çözümünde eşit işaretinin her iki tarafına aynı sayıyı ekleme veya çıkarma işlemlerinde başarısız olduğu belirlermiştir.

Denklem çözme süreçlerindeki yanılgıları ayrıntılı belirlemek için katılımcılara çeşitli problemleri nasıl çözebilecekleri sorulduğunda, eşit, küçük veya eşit, büyük veya eşit sembollerine ilişsin yanılgılarının da olduğu belirlenmiştir. Örneğin K3' ün ifadeleri şöyledir:

K3: Küçük eşitte sağ soldan küçük, büyük eşitte sağ soldan büyük... yok... ya da tam tersi bilmiyorum, ben bu büyük küçükleri biraz karıştırıyorum.

$\mathrm{K} 7$ ise $x=12$ ifadesinde $=$ sembolünün işlevi için şu ifadelere yer vermiştir:

K7: Eşitlik için burada başka sayılar da olmalı sanki (...)

Benzer şekilde diğer katılımcıların da $\leq, \geq$ ve $=$ sembollerinin anlamlarına ve işlevine dair yanılgıları tespit edilmiştir. Katılımcıların $\leq, \geq$ sembolleri için yanılgılarının söylemden kaynaklandığı belirlenirken, $=$ işareti için katılımcıların 'denge' anlamından ziyade 'işlem yapma' anlamına odaklandığı tespit edilmiştir. 
Denklem ve çözümünde katılımcılar bilinmeyeni belirlemekte, harf ile temsil etmekte ve bilinmeyenle işlem yürütmekte güçlük yaşamışlardır. Bilinmeyen kavramını açıklamaları beklendiğinde katılımcıların algılarının harfli ifade olduğu belirlenmiştir. Bilinmeyen kavramı için katılımcıların kavrayışları "hep $x$ ile gösteriyoruz", "29 harftir", “ $x$, y gibi bilinemeyenin yerine getirilen” şeklinde elde edilmiştir. Değişken kavramına dair algıların da benzer yanılgıları içerdiği tespit edilmiştir. Katılımcılar değişkeni "işlemlerin değişmesi”, "farklı harfler ile temsil etme" veya "sabit olmayan" olarak açıklamışlardır. Değişken ve bilinmeyen kavramlarını eş zamanlı olarak düşünmeleri istendiğinde katılımcılar tekrar benzer yanılgılarını sürdürmüştür. Örneğin K10' un değişken ve bilinmeyen kavramları arasındaki ilişkiyi açıklamakta yetersiz kaldığı şu ifadelerinde yer almaktadır:

K10: Değişken ve bilinmeyen... aklıma eşitsizlik geliyor. Çünkü aralık olayı var ya değişiyor sürekli, ama bilinmiyor da aynı zamanda (...)

K10' un ifadeleri eşitsizlik kavramı ile ilişkilendirmesi kavramların tanımlarına dair kavram bilgisinin olmadığını ortaya çıkarmaktadır.

Son olarak bulgularda katılımcıların temel cebir kavramlarından fonksiyon kavramına ilişkin algıları elde edilmiştir. Fonksiyon kavramının grafik temsili gibi görsel kavramlar içermesi katılımcılar için sınırlılıklar oluşturduğu belirlenmiştir. Çünkü katılımcıların sadece fonksiyonun cebirsel temsili ile tanım kümesindeki elemanların görüntüsünün belirlenmesine dair öğrenme geçmişlerinin olduğu tespit edilmiştir. Ayrıca katılımcıların kavram öğrenmelerinde, kavramın temsil türünde birbirini takip eden farklı sembollerin yer almasının da rol aldığı belirlenmiştir. K4 küme kavramının sembolik temsili için şu ifadelere yer vermiştir:

K4: (...) Kümelerle pek çalışamıyorum, parantezler, kesişim, birleşim gibi çok fazla sembol var, hatırda tutamiyorum, yazmak da zor geliyor.

Başka bir ifade ile destek eğitim araçları olmadan grafik, diyagram ve sembol temsilleri, katılımcıların cebir kavramlarını anlamalarında sınırlılık oluşturmaktadır.

\section{Tartışma}

\section{Matematik Eğitimi Uygulamalarının İncelenmesi}

Görme engelli bireylerin cebir kavramları bağlamında matematik eğitimi uygulamalarında karşılaştıkları ihtiyaçlarını ve sorunlarını incelemeyi amaçlayan bu araştırmanın sonuçları, destek eğitim uygulamalarından değerlendirme süreçlerine kadar eğitim uygulamalarının her adımını kapsamaktadır. Bu doğrultuda bireysel eğitim uygulamalarının sürdürülmesine, destek eğitim araçlarının kullanılmasına ve değerlendirme uygulamalarının tasarlanmasına ilişkin ihtiyaçlar ve sorunlar elde edilmiştir. Ancak bilişsel ve duyuşsal boyutta elde edilen sonuçlar dikkat çekmektedir. Duyuşsal boyutta yer alan sonuçlarda, matematik öğretmenlerinin görme engelli bireylere öğretim uygulamaları tasarlamada ve gerçekleştirmede tecrübesiz olmalarına dayalı olumsuz tutumlar sergilemeleri önemli bir sorun olarak karşımıza çıkmaktadır. Bu sonuç görme engelli bireyler ile kaynaştırma uygulamalarında öğretmen yetersizliklerinin (Hacısalihoğlu-Karadeniz, 2017; Karshmer vd., 2007) yansımalarına dair önemli bir sorunu ortaya koymaktadır. Bilişsel boyutta ise matematiğin doğasından kaynaklanan sembolik yapı ile kabartma yazı arasındaki ihtiyaçlara ve sorunlara dayalı bir nedensellik ilişkisi yer almaktadır.

Bulgular incelendiğinde görme engelli bireylerin mevcut durumda var olan sorunlarının, eğitim-öğretim uygulamalarındaki karşılanmayan ihtiyaçlardan kaynaklandığı söylenebilir. Karşıt olarak, çözüm bekleyen ihtiyaçların da uygulamada sorunlara yol açtığı açıktır. Bu nedenle bulgularda ortaya konulan destek eğitime, destek eğitim araçlarına, matematiğin doğasına, duyuşsal faktörlere ve sınavlara ilişkin ihtiyaçlar ve sorunlar incelendiğinde temaların birbiri ile neden-sonuç ilişkisinde olduğu söylenebilir (bk. Şekil 2). Zira not tutmaya yarayan fonksiyonel bir destek eğitim aracının olmaması ya da betimleyici bir dil kullanılmayan yetersiz bir sözlü anlatım, görme engelli bireyin matematiksel kavramları anlamasını ve işlem takibi yapmasını güçleştirmektedir. Ayrıca matematiğin sembolik yapısının destek eğitim araçları ile zenginleştirilmiş eğitim firsatlarını gerekli kılması, bu çift taraflı ilişkiyi açıklayan etkili bir örnektir. Benzer şekilde matematiğin doğasından kaynaklanan sorunlar, sınavlarda sembollerin ve işaretlerin algılanmasında ve/veya okuyucu birey ile iletişim kurmada sorunlara yol açmaktadır. Ayrıca, bulgular duyuşsal faktörlerden kaynaklanan sorunların destek eğitime duyulan ihtiyacı artırdı̆̆ını göstermektedir. 


\section{Şekil 2}

Görme Engelli Bireylerin Matematik Ĕ̈itimindeki İhtiyaçları ve Sorunları Arasındaki İlişki

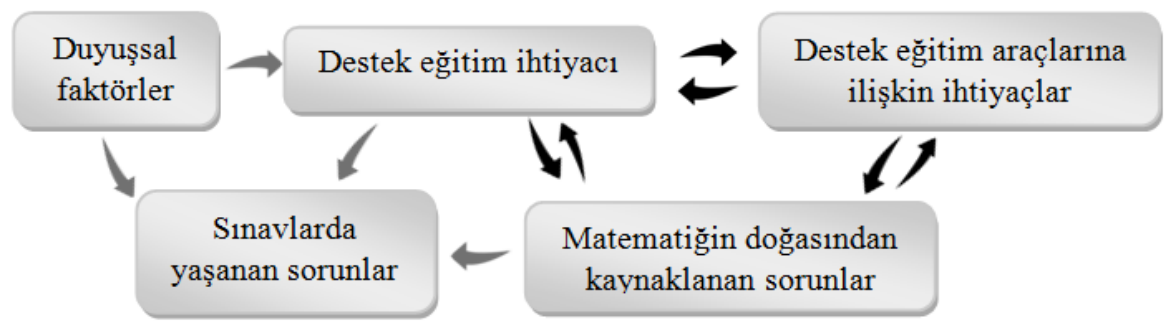

Sonuçlar matematik eğitimi özelinde ele alınmasına rağmen, büyük çerçevede destek eğitim uygulamalarını ve araçlarını kapsayan ihtiyaçlar elde edilmiştir. Farklı alan eğitimi çalışmalarında (Bayram, 2014; Kızılaslan \& Sözbilir, 2018; Zorluoğlu \& Sözbilir, 2017) da karşılaşılan sınıf düzeni, sınavlarda yaşanan sorunlar, materyal ve tekrar etme ihtiyacı gibi genel eğitim uygulamalarına dair ihtiyaçlar elde edilmiştir. Ancak matematik eğitimi özelinde ihtiyaçların ve sorunların sarmal bir yapıya sahip olduğunu söyleyebiliriz. Bulgular incelendiğinde not tutma ve yazılı materyal ihtiyaçları, bireyleri ekran okuyucu programlar kullanmaya sevk etmektedir. Ancak, matematiğin sembolik ve görsel yapısı not tutmayı güçleştirdiği gibi teknolojik materyaller için sınırlılıklar barındırmaktadır. Ayrıca matematiğin sembolik yapısından kaynaklanan sorunlar, betimleyici bir dil kullanımı ve okuyucu birey desteğini gerekli kılmaktadır. Bu gereklilikler ise öğretici ve/veya okuyucu birey ile görme engelli birey arasında matematiksel iletişim tecrübesine ve duyuşsal faktörlere dayanmaktadır. Nihayetinde sonuçlar, Şekil 2'de görüldüğü gibi birbiri ile etkileşimi olan ihtiyaçlar ve sorunlar sarmalını oluşturmaktadır. Dolayısıyla, not tutmayı kolaylaştıran ve teknolojik eksiklikleri dolduran destek eğitim araçlarının ve matematiğin doğasına uygun düzenlenmiş eğitim uygulamalarının tasarlanmasının gerektiği söylenebilir.

Matematiğin doğasından kaynaklanan ihtiyaçlar incelendiğinde, matematiğin sembolik yapısı ve matematiksel iletişime dayalı sorunlar olarak iki sonuç dikkat çekmektedir. Görsel unsurlar içermesi ve sembolik yapısından dolayı görme engelli bireylerin matematik uygulamalarında sınırlandırıldığı bilinmektedir (Aktaş, 2020; Bitter, 2013; Spindler, 2006; Şafak, 2005). Ancak Aktaş ve Argün (2020), bu sinırlılıkların yazılı ve sözlü matematiksel dil kullanımına dayandığını ortaya koymuştur. Nitekim şimdiki araştırmada da braille yazıda matematiksel sembollerin yazılmasının ve işlemlerin takip edilmesinin güçlük oluşturduğu belirlenmiştir. Bu güçlük ise matematiksel formüllerin sıklığı ve zihinden işlemlerin takibinin yetersizliği ile önemli bir soruna dönüşmektedir. $\mathrm{Bu}$ nedenle, görme engelli bireyler ile matematiksel iletişim için braille ve Latin alfabede matematik diline hakim olmanın gerekliliği dikkat çekmektedir. Sonuçlarda, öğrenme tecrübeleri dokunma duyusu ile şekillenen görme engelli bireyler için diğer bir iletişim türü olan dokunsal iletişimin yetersiz olduğu önemli bir sorun olarak yer almaktadır. Dolayısıyla görsel içerikleri betimlenme ve somut materyallerin gerekliliğini vurgulamakta yarar vardır.

Eğitim uygulamalarında, görme engelli bireyler için sınavlarda ya da sınıf uygulamalarında okuyucu birey desteğine duyulan ihtiyaç kaçınılmaz bir sonuçtur. Ancak matematiğin sembolik yapısından doğan iletişime dayalı sorunların, okuyucu bireylerin söylemlerine yansıması akademik başarısızlığı beraberinde getirmektedir (Bitter, 2013; Bülbül vd., 2012; Cowan, 2011; Zorluoğlu \& Sözbilir, 2017). Sonuçlar, okuyucu birey ile matematiksel iletişimin alan bilgisi üzerine kurulan betimleyici söylem, dokunsal iletişim ve tutum üzerine inşa edilmesinin gerektiğini ortaya koymaktadır. Görme engelli bireyler ile matematiksel iletişimde, sözlü matematiksel dilin önemli olduğu kadar yazılı dilin de önemli olduğu vurgulanmalıdır. Hatta yazılı matematiksel dil kullanımında kabartma yazının doğasından kaynaklanan güçlüklerin, matematik öğrenmede sorunları da beraberinde getirmesi alan yazını destekler niteliktedir (Aktaş \& Argün, 2020; Bitter, 2013). Ancak sonuçlar matematiksel iletişimde duyuşsal boyutun da önemli bir faktör olduğunu işaret etmektedir. Destek eğitim uygulamalarında ve sınavlarda öğreticinin, akranların ya da okuyucu bireyin kolaylaştırıcı olmaya istekli olmasının görme yetersizliği olan bireyin kaygı ve motivasyon düzeyini etkilediğini söyleyebiliriz. Nihayetinde eğitimin ayrılmaz bir parçası olan duyuşsal faktörlerin matematik eğitim uygulamalarında engel değil, destekleyici bir değişken olmasında yarar vardır. 


\section{Cebir Kavramlarının İncelenmesi}

Görme engelli bireylerin cebir kavramlarına dair kavram öğrenme süreçlerine ilişkin ihtiyaçları incelendiğinde, denklem yazmadan fonksiyon kavramına kadar temel cebir kavramlarında yanılgılarının ve kavram bilgilerinde eksikliklerin olduğu belirlenmiştir. Bu sonuçlarda elde edilen ihtiyaçların ve sorunların temelde destek eğitim uygulamalarının yetersizliğinden meydana geldiği söylenebilir. Bunun yanı sıra daha önce çeşitli araştırmaların da (Bitter, 2013; Bülbül vd., 2012; Cansu, 2014; Cowan, 2011; Edward vd., 1995; Karshmer vd., 2007) ortaya koyduğu gibi görme engelli bireylerin kavram öğrenme süreçlerinde güçlükler yaşamalarında ve kavram yanılgılarına sahip olmalarında destek eğitim araçlarının ve betimleyici dil kullanımının eksikliği de rol almaktadır. Daha ayrıntılı incelendiğinde öncelikle bireylerin, not tutmalarını ve işlem takibini sağlayacak kullanışlı bir materyale ihtiyacı olduğu söylenebilir. Ayrıca kavramların sembolik temsillerinin Latin ve braille alfabede açıklanmasının yanı sıra söylemler ile betimlenmesi önem arz etmektedir. Nitekim $=$, $\leq$ veya $\geq$ sembollerinin kullanımına dair yanılgıların, betimlemedeki yetersizliklerden ve materyal eksikliğinden kaynakladığı tespit edilmiştir. Söz konusu temel cebir kavramlarına ilişkin kavram bilgisindeki eksiklikler, bireylerin denklem ve çözüm süreçlerine yansımaktadır. Ayrıca, denklem ve çözüm süreçlerindeki sorunların işlem takibi ve zihinden işlem yapma güçlüklerinden de kaynaklandığını söyleyebiliriz. Dolayısıyla cebir kavramlarına ilişkin ihtiyaçların ve sorunların giderilmesi için öncelikle destek eğitim araçlarının tasarlanmasında yarar vardır. Böylece, sembolik matematiksel dil ile desteklenmiş uygulamalar yoluyla kavram öğrenmenin gerçekleşmesi mümkün olacaktır.

Değişken, bilinmeyen ve fonksiyon kavramlarına ilişkin ihtiyaçlar ve sorunlar incelendiğinde destek eğitim uygulamalarındaki yetersizlikler dikkat çekmektedir. Çünkü sonuçlar bireylerin değişken kavramını tanımlayamadığını, değişken ve bilinmeyen kavramlarını ayırt edemediğini ortaya koymuştur. Ayrıca bireylerin fonksiyon kavramını açıklayamaması da öğretim uygulamalarındaki sınırlılıklardan kaynaklandığı söylenebilir. Zira bireylerin sadece fonksiyonun cebirsel temsili ile çalışmaları, onların fonksiyonu denklem olarak algılamalarına zemin hazırladığı belirlenmiştir. Hâlbuki görüşmelerde kullanılan basit kabartma grafiklerle görme engelli bireylerin fonksiyon kavramına dair iki küme arasındaki ilişkiyi fark edebildiği ve ifade ettiği belirlenmiştir. Dolayısıyla görme engelli bireyler için tasarlanacak olan destek eğitim uygulamalarında, destek eğitim araçları ile zenginleştirilmiş uygulamalarla ileri düzey kazanımlara yer vermenin mümkün olduğu söylenebilir. Nihayetinde görme engelli bireylerin cebirsel kavram öğrenme düzeyinin artırılması için bireysel eğitim programlarında, söz konusu kavramlara ilişkin kazanımların ve etkinliklerin düzenlenmesi yararlı olacaktır. Ayrıca bu araştırmanın bir sınırlılığı olarak sadece cebir öğrenme alanında ele alınan ihtiyaçların ve sorunların, sayılar ve geometri gibi her bir öğrenme alanında incelenmesinde yarar vardır. Böylece görme engelli bireylerin bir bilimi öğrenmesine firsat sunulmuş olacaktır.

\section{Sonuç ve Öneriler}

Araştırmada görme yetersizlik düzeyi ve yetersizliğin başladığı döneme odaklanmaksızın elde edilen ihtiyaçlar ve sorunlar incelenmiştir. Elbette az gören ve tamamen görme kaybı olan bireylerin yazılı metinlere ve dolayısıyla matematiksel dile dair talepleri farklılık göstermektedir. Büyük puntolu metinler kullanan az gören bireyler için kabartma yazıda matematiksel dil öğrenmeleri gerekmemektedir. Ancak az gören bireyler için de not tutma güçlüğü, yazılı materyallere erişim sorunu, okuyucu birey desteği, zihinden işlem yapma güçlüğü gibi ihtiyaçların ve sorunların yer aldığı belirlenmiştir. Dolayısıyla sonuçlar ışığında görme yetersizlik geçmişine ve düzeyine bağlı olmaksızın, taleplerindeki basit farklılıklar dikkate alınarak ihtiyaçların karşılanması gerekmektedir. Sonuçlarda ortaya konulan her bir ihtiyaç ve sorun kategorisinin çözüm önerisi bekleyen birer araştırma konusu olduğu açıktır. Bunun için araştırmacıların ortaya koyacağı ayrıntılı ihtiyaç analizleri destek eğitim araçları geliştirilmesine, destek eğitim uygulamalarının tasarlanmasına ve sınav uygulamalarının düzenlenmesine katkı sunacaktır.

Araştırmanın sonuçları, Türkiye' de görme engelli bireylerin matematik eğitiminde öğrenme ihtiyaçlarına, öğretim uygulamalarına dair sorunlarına ve ölçme değerlendirme uygulamalarının yetersizliğine ilişkin önemli bir çerçeve sunmuştur. Not tutma, matematiksel sembolleri okuma gibi temel ihtiyaçlardan kavram öğrenmeye kadar çeşitli süreçlerde kullanılmak üzere destek eğitim araçlarının ihtiyacı ve cebir kavramlarına dair yanılgıların varlığı ise, araştırmanın bir sınırlığı olarak derinlemesine konu bazlı incelemelerin gerekliliğini işaret etmektedir. Böylece, görme engelli bireylerin öğrenme ihtiyaçları üzerine tasarlanacak olan destek eğitim araçları ile bireylerin kavram öğrenme süreçleri sonucunda zengin çıktılar elde edilmesi muhtemeldir. Nihayetinde araştırma sonuçları, bireysel eğitim programları tasarlayanlardan değerlendirme uygulamalarını tasarlayanlara kadar çeşitli karar mercileri için uygulama prosedürlerinin belirlenmesinde dikkate değer birer öneridir. Daha ayrıntılı ifade etmek gerekirse; elde edilen ihtiyaçlar ve sorunlar, program tasarımında ele alınacak konular ve kazanımlar, öğretim uygulamalarında yararlanılması gereken araçlar, eğitim ortamlarının tasarlaması, değerlendirmenin yapılması gibi matematik eğitimi uygulamalarının her adımının düzenlenmesine dair birer öneri niteliği taşımaktadır. 


\section{Kaynaklar}

Aktaş, F. N. (2020). Görme engelli ögrencilerin cebirsel düşünme süreçlerinin incelenmesi: Öğrenme yol haritalar [Examination of students with visual impairments algebraic thinking processes: Learning trajectories] (Tez Numarası: 611057) [Doktora tezi, Gazi Üniversitesi]. Yükseköğretim Kurulu Ulusal Tez Merkezi.

Aktaş, F. N., \& Argün, Z. (2020). Examination of mathematical language use of individuals with visual impairment in mathematical communication processes: The role of Braille. Turkish Journal of Computer and Mathematics Education, 11(1), 128-156. https://doi.org/10.16949/turkbilmat.602095

Argün, Z., Arıkan, A., Bulut, S., \& Halıcıoğlu, S. (2014). Temel matematik kavramların künyesi [Basic mathematical concepts' tag]. Gazi Kitabevi.

Aydın, P., \& Akça-Bayar, S. (2017). Görme yetersizliği: Tanım, sınıfama, yaygınlık ve nedenler. H. Gürgür \& P. Şafak (Eds.), İsitme ve görme yetersizliği [Hearing and visual impairment] içinde (ss. 128-151). Pegem Akademi.

Bayram, G. İ. (2014). Exploring the academic and social challenges of visually impaired students in learning high school mathematics (Tez Numarası: 363124) [Yüksek lisans tezi, Bilkent Üniversitesi]. Yükseköğretim Kurulu Ulusal Tez Merkezi.

Bitter, M. (2013). Braille in mathematics education [Master's thesis, Radboud University]. http://www.ru.nl

Bülbül, M. Ş. (2013). Görme engelli öğrenciler ile grafik çalışırken nasıl bir materyal kullanılmalıdır? [What sort of materials should be used while studying graphs with visually impaired students?]. Fen Eğitimi ve Araştırmaları Derneği Fen Bilimleri Ögretimi Dergisi, 1(1), 1-11.

Bülbül, M. Ş., Garip, B., Cansu, Ü., \& Demirtaş, D. (2012). Mathematics instructional materials designed for visually impaired students: Needle page. Elementary Education Online, 11(4), 1-9.

Cansu, Ü. (2014, March 20-21). Perception of visually impaired students equal sign and equality. Proceedings of the International Conference New Perspectives in Science Education, 143-146.

Cowan, H. (2011). Knowledge and understanding of function held by students with visual impairments [Doctoral dissertation, The Ohio $\quad$ State https://etd.ohiolink.edu/pg 10?0::NO:10:P10_ACCESSION_NUM:osu1316530569

Dünya Sağlık Örgütü [World Health Organization]. (2009). Visual impairment and blindness (Fact sheet no. 282). http://www.who.int/mediacentre/factsheets/fs282/en/index.html

Edwards, A. D., Stevens, R. D., \& Pitt, I. J. (1995). Non-visual representation of mathematical information. https://www.researchgate.net/publication/2246200

Hacısalihoğlu-Karadeniz, M. (2017). Öğretmen adaylarının özel eğitim ve kaynaştırma eğitiminde matematik uygulamalarına ilişkin görüşleri [Opinions of preservice teachers about special education course and mathematical applications in inclusive education]. Kalem Uluslararası Eğitim ve İnsan Bilimleri Dergisi, 7(1), 119-158. https://doi.org/10.23863/kalem.2017.78

Horzum, T., \& Bülbül, M. Ş. (2017). Görme engelliler için bir geometri öğretim materyali: Geometri kafesi [A geometry teaching material for visually impaired: Geometry cage]. Sürdürülebilir ve Engelsiz Bilim Ĕ̈itimi, 3(1), 1-15. https://doi.org/10.18197/fizikli.6

Karshmer, A. I., Gupta, G., \& Pontelli, E. (2007, July 7-9). Mathematics and accessibility: A survey. In Proc. 9th International Conference on Computers Helping People with Special Needs (Vol. 3118, pp. 664-669). https://www.utdallas.edu/\%E2\%88\%BCgupta/mathaccsurvey.pdf

Kılıç, A., Aydın, M., Ökmen, B., \& Şahin, Ş. (2019). Kuramdan uygulamaya ihtiyaç belirleme [Determining the need from theory to practice]. Pegem Akademi Yayınc1lık. 
Kızılaslan, A., \& Sözbilir, M. (2018). Görme yetersizliği olan öğrencilerin bilişsel becerileri ve psikolojik deneyimleri üzerine bir derleme [A review on the cognitive skills and psychological experiences of students with visual impairment]. Pamukkale Üniversitesi Sosyal Bilimler Enstitüsü Dergisi, 31, 29-43. https://doi.org/10.30794/pausbed.414613

Kieran, C. (1992). The learning and teaching of school algebra. In D. A. Grouws (Ed.), Handbook of research on mathematics teaching and learning (pp. 390-419). Macmillan.

Knauff, M., \& May, E. (2006). Mental imagery, reasoning, and blindness. The Quarterly Journal of Experimental Psychology, 59(1), 161-177. https://doi.org/10.1080/17470210500149992

Maulana, M. (2019, November 3). Cubaritme in the trajectory learning of multiplication concept. Proceedings of the Journal of Physics: Conference Series, 1188(1). https://doi.org/10.1088/1742-6596/1188/1/012049

Merriam, S. B. (1998). Qualitative research and case study applications in education. Jossey-Bass.

Milli Eğitim Bakanlığı [Ministry of National Education]. (2018a). Ilköğretim matematik (5, 6, 7 ve 8. sinıflar) dersi ögretim programı [Elementary mathematics curriculum (5, 6, 7 and 8th grades)]. Milli Eğitim Bakanlığı Yayınları.

Milli Eğitim Bakanlığı [Ministry of National Education]. (2018b). Ortaöğretim matematik (9, 10,11 ve 12. sınıflar) dersi ögretim programı [Secondary mathematics curriculum (9, 10, 11 and 12th grades)]. Milli Eğitim Bakanlığ Yayınları.

National Council of Teachers of Mathematics. (2000). Principles and standards for school mathematics. NCTM 20191-9988.

Özel Eğitim Hizmetleri Yönetmeliği [Special Education Services Regulation]. (2018). T.C. Resmi Gazete, (30471), 7 Temmuz 2018, 22-77.

Patton, M. Q. (2014). Nitel araştırma ve değerlendirme yöntemleri [Qualitative evaluation and research methods]. (M. Bütün \& S. Demir, Çev.). Pegem Akademi. (Orijinal kitabın yayın tarihi 2001)

Spindler, R. (2006). Teaching mathematics to a student who is blind. Teaching Mathematics and Its Applications, 25(3), 120-126. https://doi.org/10.1093/teamat/hri028

Şafak, P. (2005). Birlikte ĕgitim ortamındaki görme yetersizliğinden etkilenmiş öğrencilere gezici öğretmenlik düzenlemesine göre verilen destek hizmetin etkililiği [Effectiveness of supportive educational services provided by itinerant teacher to the visually impaired children who are placed in regular classroom] (Tez Numarası: 160524) [Doktora tezi, Gazi Üniversitesi]. Yükseköğretim Kurulu Ulusal Tez Merkezi.

Yin, R. K. (2003). Case study research: Design and methods (3rd ed.). Sage Publication.

Zebehazy, K. T., Zigmond, N., \& Zimmerman, G. J. (2012). Performance measurement and accommodation: Students with visual impairments on Pennsylvania's alternate assessment. Journal of Visual Impairment \& Blindness, 106(1), 17-30. https://doi.org/10.1177/0145482X1210600103

Zorluoğlu, S., \& Sözbilir, M. (2017). Görme yetersizliği olan öğrencilerin öğrenmelerini destekleyici ihtiyaçlar [Learning support needs of visually impaired students]. Trakya Üniversitesi Ë̆itim Fakültesi Dergisi, 7(2), 659-682. https://doi.org/10.24315/trkefd.279369 


\section{Ankara University Faculty of Educational Sciences Journal of Special Education}

2021, 22(3), 699-723

\title{
The Needs and Problems of Individuals with Visual Impairment in Mathematics Education: The Context of Algebraic Concepts*
}

\author{
Fatma Nur Aktaș $i$
}

\author{
Ziya Argün iD2 $^{2}$
}

\begin{abstract}
Introduction: Regardless of visual impairment, every student may have difficulties in learning algebra. However, algebra which has visual elements such as symbols, notations and graphics, has important limitations for individuals with visual impairment. Therefore, this study aimed to identify the needs and problems of individuals with visual impairment in learning mathematics in the context of algebraic concepts.

Method: A multiple case-embedded study design was employed. 12 participants were included. Content analysis was utilized in the qualitative data analysis obtained through semi-structured interviews.

Findings: The findings revealed five themes: Supportive and/or individualized training needs, needs for supportive training resources, problems arising from the nature of mathematics, affective factors and problems in the exams.

Discussion: The results indicated that the needs and problems formed a relational pattern that triggered each other. Therefore, when the needs and problems in the findings are examined, the themes are in a cause-effect relationship with each other.

Conclusion and Suggestions: Although the results are discussed specifically for mathematics education, needs covering supportive education applications and tools, in general, have been determined. It is obvious that the needs that are waiting for a solution cause the problems in practice. The participants with visual impairment were reported to hold misconceptions about the concepts of variable, unknown, equation and its solution, equality, inequality, function along with the lack of concept knowledge. Accordingly, there is a need for concept-oriented research to improve educational practices.
\end{abstract}

Keywords: Individuals with visual impairment, mathematics education, algebraic concepts, needs, problems.

To cite: Aktaş, F. N., \& Argün, Z. (2021). The needs and problems of individuals with visual impairment in mathematics education: The context of algebraic concepts. Ankara University Faculty of Educational $\begin{array}{lllll}\text { Sciences Journal of Special } & \text { Education, }\end{array}$ https://doi.org/10.21565/ozelegitimdergisi.750682

\footnotetext{
*This article is an extended version of the presentation entitled "Current Situation Analysis of Individuals with Visual Impairment in Mathematics Education: Needs and Problems" presented at the $4^{\text {th }}$ International Symposium of Turkish Computer and Mathematics Education.

${ }^{1}$ Corresponding Author: Res. Assist., Dr., Kahramanmaraş Sütçü İmam University, fatmanuraktas@ksu.edu.tr, https://orcid.org/0000-0000-1234-5678

2Prof. Dr., Gazi University, ziya@ gazi.edu.tr, https://orcid.org/0000-0000-1234-5678
} 


\section{Introduction}

Education is among the basic human rights to be offered to individuals in line with their needs, strengths and weaknesses. Regarding those students who engage in individual education programs and need special education, the curriculum, supportive training resources and assessment processes that consider their individual characteristics are insufficient (Zorluoğlu \& Sözbilir, 2017). In addition, since individuals with visual impairment (IVA) cannot receive the visual information such as symbols and shapes for mathematics education, they are among the priority groups (Spindler, 2006). This plays a role in important issues such as the lack of mathematical skills and career choices that belong to IVA. Therefore, identifying the difficulties arising from the nature and abstract structure of mathematics and suggesting solutions are required. Previous studies on the comprehension and understanding of IVA regarding basic algebraic concepts reveal similarities and differences in learning in the context of needs based on vision (Aktaş, 2020; Knauff \& May, 2006; Maulana, 2019; Spindler, 2006). Therefore, basic algebraic concepts (variable, unknown, equality, equation, generalization, function) are discussed in this research.

Needs analysis provides the opportunity to identify the expectations and requirements that reveal the current situation. As a matter of fact, the needs analysis is found extensively from curriculum development to planning a course in educational practices (Kılıç et al., 2019). The purpose of the current research is to identify the needs and problems of IVA in mathematics education. The research questions are stated in the following:

1. What are the needs and problems of IVA in mathematics education?

2. What are the learning needs of the IVA regarding the algebraic concepts?

\section{Method}

\section{Research Design}

This study was designed as a case study which provided the opportunity to reveal the results with a holistic interpretation by examining the current situation in its context (Merriam, 1998). Since the current study aimed to identify the needs and problems of IVA, each participant constituted a case of the research. Therefore, the study was designed as a multiple-case embedded research (Yin, 2003).

\section{Participants}

The level of visual impairment and the period of the vision loss play role in oral and written mathematical language use skills (Aktaş \& Argün, 2020). Therefore, the participants with different demographic characteristics, types of visual impairment and medical-developmental background were recruited by the maximum variation sampling method. In addition, each participant contributed to contact with IVA whom they thought would provide rich information after the interviews. Thus, the snowball sampling method was also utilized. According to the criteria of using large font Latin letter or braille, color-light perceptions and no concomitant disability or impairment as well as identifying the vision rates by Counseling and Research Center [CRC] or medical report, the criterion sampling method were utilized to include the participants. Information about the participants was presented in Table 1.

\section{Table 1}

Information About Participants

\begin{tabular}{cccccccc}
\hline $\begin{array}{c}\text { Name } \\
\text { (code) }\end{array}$ & $\begin{array}{c}\text { Vision loss rate } \\
\text { (CRC/medical } \\
\text { report) }\end{array}$ & $\begin{array}{c}\text { Period of } \\
\text { vision loss }\end{array}$ & $\begin{array}{c}\text { Perception } \\
\text { of light }\end{array}$ & $\begin{array}{c}\text { Perception } \\
\text { of color }\end{array}$ & $\begin{array}{c}\text { Knowing } \\
\text { braille }\end{array}$ & $\begin{array}{c}\text { Knowing/using } \\
\text { Latin alphabet }\end{array}$ & Education/occupation \\
\hline K1 & $85 \%$ & Congenital & A & N/A & Yes & No & $\begin{array}{c}\text { Anatolian High School } \\
\left(12^{\text {th }} \text { Grade }\right)\end{array}$ \\
K2 & $80 \%$ & Congenital & A & A & Yes & Yes (Uses) & $\begin{array}{c}\text { Anatolian High School } \\
\left(12^{\text {th }} \text { Grade }\right)\end{array}$ \\
K3 & $90 \%$ & Congenital & A & N/A & Yes & No & $\begin{array}{c}\text { Anatolian Imam Hatip } \\
\text { High School (Alumni) }\end{array}$ \\
K4 & $85 \%$ & Congenital & A & A & Yes & No & $\begin{array}{c}\text { Anatolian High School } \\
\text { (Alumni) }\end{array}$ \\
\hline
\end{tabular}


Table 1 (continue)

\begin{tabular}{|c|c|c|c|c|c|c|c|}
\hline $\begin{array}{l}\text { Name } \\
\text { (code) }\end{array}$ & $\begin{array}{c}\text { Vision loss rate } \\
\text { (CRC/medical } \\
\text { report) }\end{array}$ & $\begin{array}{l}\text { Period of } \\
\text { vision loss }\end{array}$ & $\begin{array}{l}\text { Perception } \\
\text { of light }\end{array}$ & $\begin{array}{l}\text { Perception } \\
\text { of color }\end{array}$ & $\begin{array}{c}\text { Knowing } \\
\text { braille }\end{array}$ & $\begin{array}{l}\text { Knowing/using } \\
\text { Latin alphabet }\end{array}$ & Education/occupation \\
\hline K5 & $90 \%$ & Congenital & A & A & Yes & No & $\begin{array}{l}\text { Anatolian İmam Hatip } \\
\text { High School (Alumni) }\end{array}$ \\
\hline K6 & $90 \%$ & At 12 & A & A & Yes & Yes (Does not use) & $\begin{array}{l}\text { Department of Social } \\
\text { Sciences (Sophomore) }\end{array}$ \\
\hline K7 & $85 \%$ & Congenital & A & A & Yes & Yes (Does not use) & $\begin{array}{l}\text { Department of Turkish } \\
\text { Language (Freshman) }\end{array}$ \\
\hline K8 & $90 \%$ & Congenital & A & A & Yes & No & $\begin{array}{l}\text { Department of Sociology } \\
\text { (Sophomore) }\end{array}$ \\
\hline K9 & $90 \%$ & $\begin{array}{l}\text { Between } \\
7-12\end{array}$ & A & A & No & $\begin{array}{l}\text { Yes (Uses 18-font size } \\
\text { condensing lens) }\end{array}$ & $\begin{array}{l}\text { Mechanical Engineer } \\
\text { (Junior) }\end{array}$ \\
\hline K10 & $90 \%$ & $\begin{array}{l}\text { Between } \\
7-10\end{array}$ & N/A & N/A & Yes & Yes (Only writes) & $\begin{array}{l}\text { Department of Psychology } \\
\text { (Senior) }\end{array}$ \\
\hline K11 & $70 \%$ & $\begin{array}{l}\text { Between } \\
12-20\end{array}$ & A & A & No & $\begin{array}{l}\text { Yes (Uses 16-font size } \\
\text { condensing lens) }\end{array}$ & IT Engineer \\
\hline K12 & $85 \%$ & $\begin{array}{l}\text { Between } \\
1-25\end{array}$ & A & A & Yes & Yes (Only writes) & Academic \\
\hline
\end{tabular}

\section{Data Collection Tools}

In this study, the data were obtained through semi-structured individual interviews. The questions in the interview form focused on the level of visual impairment, mathematics learning processes, mathematical concepts in daily life skills, their knowledge of algebraic concepts and their deficiencies. Firstly, previous studies handling the problems and needs of IVA were examined (Bayram, 2014; Bitter, 2013; Bülbül et al., 2012; Edwards et al., 1995; Karshmer et al., 2007; Kızılaslan \& Sözbilir, 2018; Spindler, 2006). The nature of the concepts for algebraic concepts, their definitions, student comprehension and curriculum were examined in detail (Argün et al., 2014; Kieran, 1992; MEB, 2018a, 2018b). This examination was blended with studies on teaching mathematics for IVA (Aktaş, 2020; Bülbül, 2013; Cansu, 2014; Cowan, 2011; Şafak, 2005). The interview form was prepared as a result of expert opinions from three academics. In line with these opinions, the steps to see the texts written in various font sizes and distinguish the objects according to their colors were added for the level of visual impairment. Afterwards, the interview form took its final form with the pilot study which included two participants with visual impairment who were following the $12^{\text {th }}$ grade. One was congenitally blind (no color and light perception) and the other had $80 \%$ vision loss. The first participant used braille, cubarithm arithmetic board, and braille slate. Following the pilot study, the arrangements were made regarding the braille and graphics in the interview form.

Sample questions from the interview form were presented below:

1. Personal information: What are/were the difficulties you encounter in inclusive education practices? What are/were the materials you use in teaching practices? If you have/had any problems, could you please share your problems arising from these materials?

2. Information about mathematics education and practices: Could you share an effective mathematics lesson that you remember?, What are/were the difficulties that you have/had while learning mathematics? Could you explain the concepts you need/needed for supportive training resources (if there are)?

3. Information about algebraic concepts: What are/were the difficulties you experience/experienced while learning algebraic concepts such as variable, equation and function? What are/were the difficulties you had with the strategies used for those concepts by your teachers? Check out the table showing the daily amount of forage consumption in a zoo. How do you represent the relationship between these two sets? Can you express this relationship algebraically? 


\section{Figure 1}

Tactual Materials Used for The Representation of The Tables and Graphics in The Interviews
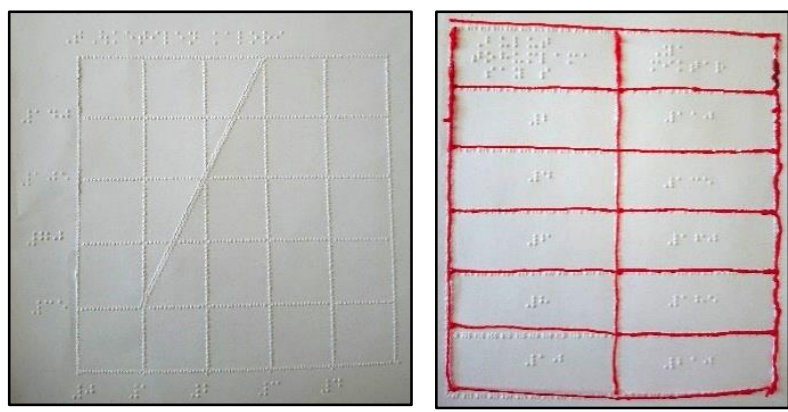

Since the hand movements of IVA were important when examining diagrams and graphics, the interviews were video-recorded. These recordings were among the other data collection tools.

\section{Data Collection and Analysis}

Semi-structured interviews were conducted in quiet places with the participants. The interviews were held in one or two sessions (in April-August 2018). The duration of the interviews was between 90 to 120 minutes. They were video-recorded. The steps of the content analysis suggested by Merriam (1998) were followed in data analysis. The data were transcribed and read only once. Subsequently, important statements were marked for each participant, reflective notes were taken and categories were created. In the light of the literature review (Bitter, 2013; Edwards et al., 1995; Kızılaslan \& Sözbilir, 2018; Spindler, 2006), the categories were discussed. The categories that could be gathered under a single main idea were discussed under themes.

\section{Findings}

\section{Needs and Problems in Mathematics Education Practices}

The problems stated by the participants included classroom practices, national exams and passing exams, supportive training practices and communication with individuals and the needs as a result of these problems were presented in Table 2 .

\section{Table 2}

Needs and Problems of Visually Impaired Individuals in the Mathematics Education

\begin{tabular}{|c|c|}
\hline Themes & Categories \\
\hline \multirow{11}{*}{ Supportive and/or individualized training needs } & Learning strategy \\
\hline & Needs and problems of narration and description \\
\hline & Problems with the lack of experience \\
\hline & Needs for classroom arrangements \\
\hline & Needs for reviews \\
\hline & Problems about following the lessons \\
\hline & Deficiency regarding kinesthetic communication \\
\hline & Reader needs and problems \\
\hline & $\bullet$ Need for peer support \\
\hline & - Reader-student interaction \\
\hline & - Reader related problems \\
\hline \multirow{6}{*}{ Needs for supportive training resources } & Written material needs \\
\hline & Technological material needs \\
\hline & Concrete material needs \\
\hline & Difficulty in note-taking \\
\hline & Screen reader problems \\
\hline & Voice-recording problems \\
\hline
\end{tabular}


Table 2 (continue)

\begin{tabular}{ll}
\hline \multicolumn{1}{c}{ Themes } & \multicolumn{1}{c}{ Categories } \\
\hline & Not knowing Latin letters and numbers \\
Difficulty in mental calculation & Frequency of mathematical operations \\
Problems arising from the nature of mathematics & $\begin{array}{l}\text { Difficulty in mathematics in braille } \\
\text { Problem regarding abbreviation use }\end{array}$ \\
Symbols and signs & Mathematical formulas \\
Affective factors & Access problem to visual content \\
& Attitudes of the individuals (teacher, peer and reader) \\
Anxiety & Loss of motivation \\
& Problem regarding the reader \\
& Symbols and signs \\
& Type of the exam
\end{tabular}

\section{Supportive and/or Individualized Training Needs}

The most remarkable category under this theme was the lack of experience of the participants and their teachers in learning mathematics together. The participants who completed primary school for the visually impaired stated that they faced various difficulties such as following the lesson and classroom arrangement as they involved in the inclusive education in secondary education. It was reported that the problem of communicating with the mathematics teacher in the Latin alphabet apart from braille stemmed from the lack of experience in communication. Similarly, there was a lack of experience of mathematics teachers who had not prepared the content and design of the lessons for the person with visual impairment before. Continuing his education at inclusive schools, K9 explained this in the following: "When I graduated from high school, I started getting prepared for the exam with four operations. This was because they let me pass without knowing anything (...)".

While K12 related mathematics to daily life, he spoke about the problems the students with visual impairment faced while gaining concrete experiences. K1 stated that one may not possess mathematical knowledge by saying: "(...) If someone has never played a candle in his life, if he doesn't know how the candle burns and melts in time, it may be a problem". Although the participants attended mathematics lessons, they stated that they had difficulty in following the lessons. In addition to the lack of teacher experience and difficulties in following the lessons, the need for reader was highlighted.

The participants, especially those who got involved in the inclusive education for the first time, had problems with engaging in mathematical communication with their teachers, peers and readers. Another variable that strengthened the reader problem was categorized as inadequacies in narration (verbal expressions). It was clear that the participants needed the use of a descriptive language in the mathematics lesson that was designed for them. The need for a reader also arised during the course reviews. Since the difficulty in following the lesson caused the individual to have difficulties in note-taking, reader support was needed from sighted peers or teachers for the reviews. In addition, classroom arrangement was another variable that made it difficult to follow the lesson. The access of the visually impaired individuals to the information on the board in the inclusive classes affected the individual's and his/her peers' seating arrangement in the classroom.

The problems in teaching strategies included the absence of a descriptive language in narration, the absence of remarkable tasks and concrete materials. Another category that supported these problems was the lack of kinesthetic communication activities such as drawing in the palm, working with tactile instruments.

\section{Needs for Supportive Training Resources}

It was observed that the participants needed various materials in learning maths. There were needs for printing and accessing braille alphabet or texts in large fonts. However, this need increased with the problem that visual mathematical contents such as equations and symbols which could not be read by common screen reader programs. Since it was difficult to take notes with the braille tablet and the braille alphabet, the lack of material 

THE CONTEXT OF ALGEBRAIC CONCEPTS

for note-taking was noteworthy. One of the ways that participants used to overcome this problem was to record the lesson. However, the inadequacy of voice-recorded resources emerged as important needs. The difficulties faced by the participants while listening to the voice-recordings supported the category of developing technological materials. K3 mentioned the lack of technological programs in the following: "We do not have written materials, it is necessary to convert the resources to electronic documents for screen reader programs, but we cannot scan with mobile phones. It's a very difficult task for us."

\section{Problems Arising from the Nature of Mathematics}

Participants stated that they had difficulties in the use of symbols and signs frequently in the algebraic concepts, their description conducted by the readers and representation in braille. It was found that the representation differences of symbols in Latin and braille alphabet caused the participants to have difficulties in using mathematical language with readers. Not knowing the Latin letters and numbers and the use of mathematical symbols and signs frequently was at the core of the problems of participants in learning mathematics. In inclusive practices, it can be said that mathematics teachers and readers who do not have experience in the instruction of those with visual impairment and who do not have full knowledge of braille codes, make mathematical communication and therefore conceptual understanding difficult. In addition, the representation of mathematical symbols and signs in braille contains more than one code, the lack of full knowledge of these codes and difficulties in note-taking of mathematical operations refer to the difficulty of mathematics in braille.

It was reported that the participants had difficulty in following the mathematical operations due to the symbolic language use and the difficulties of note-taking in braille. For example, K1 stated the problems he experienced in the following: "I think it is a little bit difficult to do mathematics in braille (...) Since I can not write the operations one under the other, there are methods of operations for equations, I can not understand them at all". In addition, the participants emphasized that they preferred to perform mental calculation due to the difficulties in note-taking, but they could not follow the operations consecutively. The participants mentioned the frequency of mathematical formulas as well as the obstacles due to the nature of mathematics such as the use of symbolic language and the follow-up.

\section{Affective Factors}

It was observed that the participants had difficulties in the learning process when they experienced the inclusion for the first time. Regarding the attitude of the teachers in the classroom, K7 stated: "He was acting as if I were not in the class. For example, he could say 'you solve this question', but we had no communication in the classroom." In addition, the participants stated that their peers did not want to support them as a reader during the follow-up.

\section{Problems in the Exams}

Regarding passing the maths and national exams, the participants mentioned the problems related to the assessment procedures such as exam type and visual content as well as problems related to the readers. The participants drew attention to the reader's attitudes, motivation based on the reader's symbol knowledge and mathematical communication in national exams. The participants stated that the individuals who helped the exams generally had insufficient knowledge about mathematical concepts and symbols and were reluctant to repeat the questions.

\section{Learning Needs About the Algebraic Concepts}

First of all, the problems faced by the participants in the equation and solution steps are noteworthy. It was seen that the participants had difficulties particularly in identifying the information and knowledge given in the problem, expressing the equation according to this determination and performing algebraic operations. Hereby, the participants did not have the conceptual knowledge of identifying the unknown and perform operations with algebraic expressions. In addition, it was observed that the participants had misconceptions regarding the $=, \leq, \geq$ signs and symbols. For example, K3 stated the following: "Right is less than left with less-than or equal sign, right is greater than left with the greater-than or equal sign... no... or vice versa I don't know". It was pointed out that while the misconceptions of the participants regarding the $\leq, \geq$ signs stemmed from the discourse, the participants focused on meaning of 'making operation' for '=' sign. The participants had difficulty in identifying the unknown, representing it in letters, and making operations with the unknown. When they were expected to explain the 
THE CONTEXT OF ALGEBRAIC CONCEPTS

concept of unknown, the perceptions of the participants were determined to be an explanation with letters. It was seen that the participants had learning experiences about only the function of algebraic representation and the visual identification of the elements in the definition set. In addition, including different symbols played a role in the concept learning. K4 explained this in the following: "(...) I can't study with the sets, there are too many symbols like parentheses, intersections, union, I can't remember, it's also hard to write them".

\section{Discussion}

\section{Results on Mathematics Education Practices}

When the findings are examined, it can be said that the current problems of IVA stem from unfulfilled needs in educational practices. However, it is obvious that the needs that are waiting for a solution cause the problems in practice. Therefore, when the needs and problems in the findings are examined, the themes are in a cause-effect relationship with each other (see Figure 2). The lack of a functional supportive training resource for note-taking or an inadequate narration without a descriptive language makes it difficult for the IVA to understand mathematical concepts and follow the operations. In addition, the fact that mathematics requires educational opportunities enriched with supportive educational resources is an effective example explaining this two-sided relationship.

\section{Figure 2}

The Relationship Between the Needs and Problems of IVA in Mathematics Education

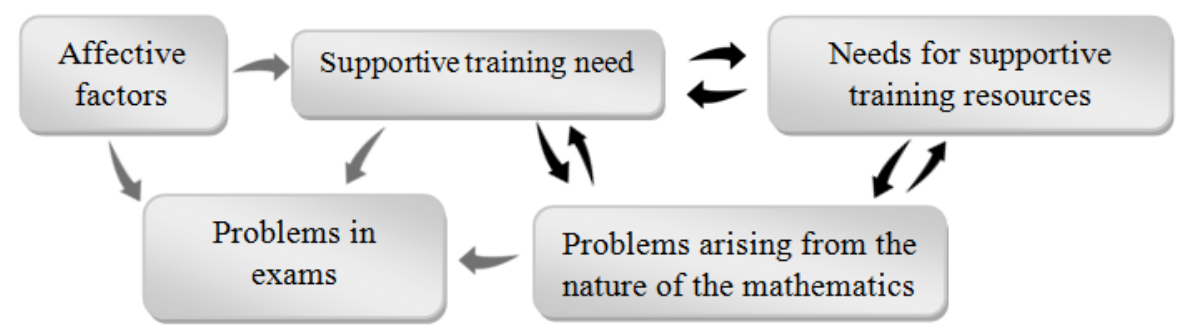

It is observed that the needs of note-taking and written material lead the individuals to use screen reader programs. However, the symbolic and visual structure of mathematics makes it difficult to take notes. There are restrictions for technological material as well. In addition, these problems necessitate descriptive language and reader-individual support. These requirements are based on mathematical communication experience and affective factors between the instructor and/or reader and the IVA. Ultimately, the results form the chain of needs and problems that interact with each other as can be seen in Figure 2. Therefore, supportive education resources that facilitate note-taking and educational practices arranged in accordance with the nature of mathematics that remove the technological limitations need to be designed.

The problems regarding the symbolic structure of maths and mathematical communication were evident based on the responses of the participants. It is known that IVA are restricted in mathematics practices since they include visual elements and symbolic structure (Aktaş, 2020; Bitter, 2013; Spindler, 2006; Şafak, 2005). However, Aktaş and Argün (2020) revealed that these restrictions stemmed from the use of written and verbal mathematical language. The current study also showed that that it was difficult to write mathematical symbols and follow the operations in braille. This difficulty turned into an important problem with the frequency of mathematical formulas. The participants were not able to follow the mental calculations. Therefore, a comprehensive knowledge of mathematical communication with IVA in braille and Latin alphabet is necessary.

\section{Conclusion and Suggestions}

It was seen that IVA had misconceptions in fundamental algebraic concepts that ranged from equation to the function. The needs and problems might be mainly caused by insufficient supportive training practices. In addition, the lack of supportive training resources and descriptive language played a role in the learning process of IVA including their misconceptions. These individuals need a functional material that will help them take notes and follow up the operations. Besides, it is important to describe the symbolic representations of the concepts in 
Latin and braille alphabet as well as to explain them with specific instructions. The misconceptions on the use of " $=, \leq$ or $\geq "$ symbols stemmed from the lack of description and material. In addition, the problems in the equation and solution processes arose from the difficulties of following the operations and mental calculations.

Insufficient supportive training resources were noteworthy in that the individuals could not define and distinguish the concepts including variable and unknown. In addition, it can be said that the inability of individuals to explain the concept of function was due to the restrictions in instruction. It was observed that the participants studied the algebraic representation of the function only, which led to the perception of the function as an equation. Thus, important clues about basic algebraic concepts could be presented to those designing individualized education programs and working on conceptual understanding. 